\title{
AMERICA'S INVISIBLE CHILDREN Latino Youth and the Failure of Justice
}

By NEELUM ARYA with FRANCISCO VILLARRUEL, CASSANDRA VILLANUEVA, and IAN AUGARTEN Foreword by JANET MURGUÍA and JUAN SÁNCHEZ

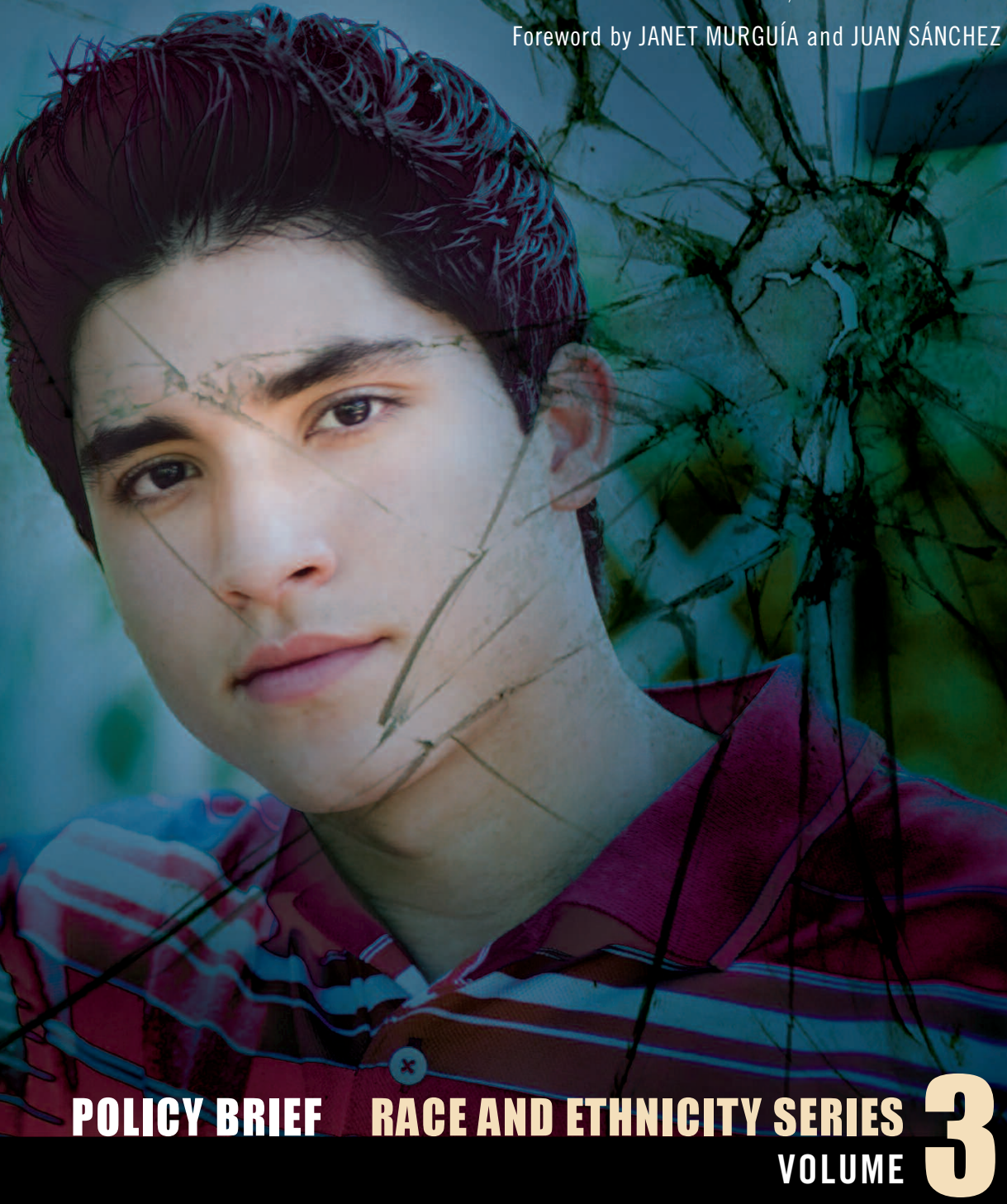


The Campaign for Youth Justice (CFYJ) is a national organization dedicated to ending the practice of trying, sentencing, and incarcerating youth under the age of 18 in the adult criminal justice system. CFYJ gratefully acknowledges our funders who support our work, including the Annie E. Casey Foundation, the Chasdrew Fund, the Eckerd Family Foundation, the John D. and Catherine T. MacArthur Foundation, the Open Society Institute, the Public Welfare Foundation, and individual anonymous donors.

The National Council of La Raza (NCLR) is the largest national Latino civil rights and advocacy organization in the United States, working to improve opportunities for Hispanic Americans. NCLR gratefully acknowledges funding from the John D. and Catherine T. MacArthur Foundation which supports NCLR's participation in the Models for Change initiative and the development of the Latino Juvenile Justice Network. 


\section{AMERICA'S \\ INVISIBLE CHILDREN \\ LATINO YOUTH AND THE \\ FAILURE OF JUSTICE}

This policy brief is dedicated to the thousands of

Latino youth and families across America who have been

harmed by laws and policies that allow youth to be tried

in the adult criminal justice system and incarcerated

in adult jails and prisons. 


\section{FOREWORD}

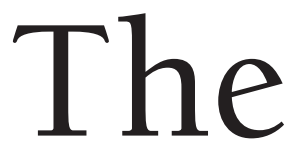

face of America is changing. The number of Latino youth in this country has almost doubled in the last decade, and on any given day close to 18,000 Latino youth are incarcerated in America. ${ }^{1}$ Youth who dream of becoming the teachers, doctors, and mayors of our communities are instead arrested and locked away their dreams shattered. A significant majority of these incarcerated youth are non-violent offenders who only become "chronic offenders" after serving time behind bars. Most disturbing is that one out of every four incarcerated Latino children is held in an adult prison or jail even though youth in adult facilities are in significant danger of suicide and rape.

This country's juvenile justice system is in crisis. At the heart of the crisis is our failure to recognize that this system is for the care and treatment of children, not simply the punishment and correction of criminals. If we were to start over and redesign the system with our own children in mind, it would look very different.

Despite these grim statistics, victories in recent years have provided hope that the conditions for Latino youth can and will improve. Scandals over conditions of confinement in California and Texas have caused both states to initiate serious conversations about the need to reform their juvenile justice systems. Victories in Illinois and Connecticut that will raise the age of juvenile court jurisdiction will reduce the number of Latino youth automati- 
cally tried in the adult system in those states. Programs developed within the Latino community are profiled in this brief. These programs are working every day to improve the lives of our young people who have contact with the justice system.

For so long we have known what works (and what doesn't work) in combating juvenile delinquency, but this country has lacked the political will, leadership and courage to see these reforms through. As our nation rethinks the large-scale institutionalization of youth and reevaluates trying youth as adults, the juvenile justice community in general and the Latino community in particular has a unique opportunity to help refocus and reprioritize our nation's justice system around key principles known to work with Latino youth and families. In addition to the more than 300 community-based organizations that make up the National Council of La Raza Affiliate Network, Latino leaders and social service providers exist all over the country who could be resources if and when justice systems choose to invest in community solutions instead of incarceration. Latino leaders and policymakers must insist that the juvenile justice system in America treat our children and youth in a manner that truly educates and rehabilitates them so they can succeed at home and contribute to our democratic society.

The policy recommendations included in this brief are clear action steps that policymakers can take today to reduce the harm caused by transferring Latino youth to the adult justice system and incarcerating them in adult jails and prisons. In addition, we hope the information in 
this brief will encourage a broader conversation about how to reform our justice system to achieve better outcomes for all youth.

The values employed by Southwest Key Programs, programs that have served the needs of Latino children and families for more than 20 years, are one example of principles on which to base a new system of justice:

- Children flourish when they are able to remain at home with their families in a supportive environment.

- Youth do not fare well in institutions, but are helped much more significantly by communitybased organizations that can enable families to play a critical role in the treatment process.

- Effective services must be culturally competent and delivered by persons knowledgeable of cultural, language, and ethnic differences.

- Every young person must actively participate in the design of their own strength-based service plan. 
Southwest Key Programs is just one example of the numerous organizations providing community-based alternatives to incarceration for Latino youth. This country needs to encourage and fund these solutions, and those that focus on preventing youth from ever becoming involved in the criminal justice system in the first place. We need a new approach that enables our Latino children to dream, and dream big, while providing them with the tools they need to accomplish those dreams.

Janet Murguía

President and CEO

National Council of La Raza

Juan Sánchez

Founder and CEO

Southwest Key Programs, Inc. 


\section{OVERVIEW}

Latino ${ }^{i}$ youth are treated more harshly by the justice system than white youth, for the same offenses, at all stages in the justice system including police stops, arrests, detention, waiver to the adult criminal justice system, and sentencing. ${ }^{2}$ The first national analysis of the disparate treatment of Latino youth in the justice system, ¿Dónde Está la Justicia?, was released in 2002. Two years later, the National Council of La Raza (NCLR) released Lost Opportunities: The Reality of Latinos in the U.S. Criminal Justice System, providing a similar review of Latinos in the criminal justice system. ${ }^{3}$ Both works documented how Latinos were virtually invisible in studies and publications in the justice field, and how state and federal agencies neither collected accurate data nor published Latino justice data if available. Not surprisingly, Latinos were rarely included in policy debates in the juvenile or criminal justice field.

To ensure that the needs of Latino youth and families are heard and represented in current policy debates, the Campaign for Youth Justice and NCLR embarked upon compiling the most recent information available about Latino youth in the justice system, with a particular focus on youth tried as adults. This policy brief, like its predecessors, includes some sobering findings:

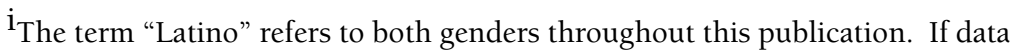
refer to male or female populations, the distinctions will be noted clearly. 
- On any given day, close to 18,000 Latino youth are incarcerated in America.The majority of these youth are incarcerated for non-violent offenses. Most Latino youth are held in juvenile detention facilities (41\%) and juvenile long-term secure facilities (34\%). However, one out of every four (24\%) incarcerated Latino children is held in an adult prison or jail even though youth in adult facilities are in significant danger of suicide and rape. ${ }^{4}$

- Latino youth are overrepresented in the U.S. justice system and receive harsher treatment than white youth. In order of rising disparities, Latino youth are: $4 \%$ more likely than white youth to be petitioned; $16 \%$ more likely than white youth to be adjudicated delinquent; $28 \%$ more likely than white youth to be detained; $41 \%$ more likely than white youth to receive an out-of-home placement; $43 \%$ more likely than white youth to be waived to the adult system; and $40 \%$ more likely to be admitted to adult prison. ${ }^{5}$ States with the highest levels of disparity of Latino youth in adult prison (rates over 5 times that for white youth) were California, Minnesota, North Dakota, Pennsylvania, and Wisconsin. ${ }^{6}$ 
- Nine out of ten (90\%) Latino youth ages 10 to 17 live in states that permit the pre-trial detention in adult jails for youth prosecuted in the adult system. ${ }^{7}$

According to a study of 40 large urban jurisdictions, Latino youth prosecuted in the adult system are routinely incarcerated in adult jails. Overall, a higher proportion of white youth are released pretrial $(60 \%)$ than any other racial or ethnic categories. Most (54\%) Latino youth prosecuted in the adult system were detained pretrial; of the Latino youth detained pretrial, $72 \%$ were held in adult jails. ${ }^{8}$

There is no simple answer to the question of why Latino youth are being treated so unfairly, but these disparities cannot continue to go unaddressed. According to a Pew Hispanic Center survey released in 2009, almost one in five (18\%) native-born-Latinos say they or someone in their immediate family served time in jail or prison in the previous five years. ${ }^{9}$

This brief begins with an overview of disparities and structural racism, a review of Latino demographic characteristics, and a discussion of the immigration and crime connection and stereotypes about Latino youth. Second, this brief then takes an in-depth look at disparities that exist at all major decision points in the justice system, supplementing national data with data from California and Arizona. This section explains how the majority of Latino youth are arrested for non-violent offenses, yet many of these youth are removed from their homes and sent to locked incarceration-type facilities far away from their homes. Failure to provide culturally and linguistically competent services to families contributes to these dis- 
parities. Third, this brief looks at national initiatives that have been successful at reducing racial and ethnic disparities, particularly in detention facilities, for Latino youth. Fourth, this brief profiles several community-based models working with Latino youth and families.

Finally, the brief concludes with a series of recommendations for federal and state policymakers to reduce the racial and ethnic disparities of the justice system. The recommendations fall into two major categories:

- Stop the most harmful and dangerous laws, policies, and practices that affect Latino youth. Reduce the transfer of Latino youth to the adult system, reduce the over-incarceration of youth in juvenile facilities, and stop the incarceration of youth in adult jails and prisons. Reconsider law enforcement tactics and the impact of policies related to racial and ethnic profiling, enforcement of gang statutes, and the negative effect that immigration enforcement policies have on Latino youth.

\section{- Focus on building culturally competent services and} programs to serve the needs of Latino youth and families. Redirect resources from incarceration to build a network of community-based programs to provide culturally competent services and programs to serve the needs of Latino youth and families. If youth do have contact with the justice system, ensure that youth and their families are treated fairly in court and by the juvenile justice system by ensuring that their cultural and linguistic needs are met. 


\section{DISPARITIES AND STRUCTURAL RACISM}

The words "overrepresentation," "disproportionality," and "disparity" are often used interchangeably to describe how some groups of children are more likely than would be expected to be found within the justice system given their representation in the general child population. However, using the terms interchangeably hides important relationships among the concepts.

- "Overrepresentation" exists when, at various stages of the justice system, the proportion of a certain population exceeds its proportion in the general population.

- "Disproportionality" exists when, at various stages of the justice system, the proportion of a certain population either exceeds, as in the case of overrepresentation, or is below, as in the case of underrepresentation, its proportion in the general population.

- "Disparity" refers to a situation in which different groups have different probabilities or likelihoods that certain outcomes will occur. Disparities produce disproportionality.

Although most studies analyzing disparities of the justice system start with arrest, as with most matters of race and ethnicity in the U.S., disparities do not begin at arrest, but at the "starting gate" - the social contexts into which many Latino youth are born. ${ }^{10}$ For example, almost 
one-third of Latino children under age 18 (29\%) were living in poverty in 2007 , nearly three times the proportion of white non-Latino youth (10\%). ${ }^{11}$ Whether these children have equal access to quality early childhood programs, elementary and secondary education, afterschool programs, or health and mental health services, will, intentionally or not, produce outcomes that will chronically favor or disfavor certain racial or ethnic groups, and have a direct impact on whether Latino youth enter the justice system.

The disproportionality, specifically the overrepresentation of Latino youth in the adult justice system, is not fully understood but is likely to be explained by a combination of undesirable adolescent behavior and disparate responses by adults in our society to that behavior. Throughout this brief we will address stereotypes that contribute to perceptions that Latino youth are somehow different from, and more dangerous than, non-Latino youth. We believe that these perceptions may account for at least some of the disparate treatment that Latino youth experience in the justice system.

\section{LATINOS INVISIBLE IN THE BLACK-WHITE PARADIGM}

One obstacle confronting Latinos in their search for justice is the black-white paradigm of race in America. Our familiarity with the legacy of slavery and segregation provides a context for understanding the mistreatment that African Americans suffer at the hands of the police or the prison-industrial complex. This knowledge helps explain the abuses we see, and it gives us an appropriate 
degree of suspicion when new laws or practices appear to impact African Americans more than members of other groups. ${ }^{12}$

Even though criminal laws have been used to discriminate against Latinos in this country since the passage of the "Greaser Act," an anti-vagrancy law in 1855 in California, we do not have the same level of understanding about the mistreatment of Latinos in this country. ${ }^{13}$ Most Latinos have also been affected by a series of events and practices that have similarly affected their political, social, and economic advancement. ${ }^{14}$ From the Treaty of Guadalupe-Hidalgo to the contemporary anti-immigrant movement, Latinos have faced systematic discrimination and abuses that are just as detrimental as, but operate differently from, those directed at the African-American community. However, our courts have not always known how to recognize discrimination against Latinos. For example, in the 1991 case, Hernandez v. New York, the U.S. Supreme Court saw no discrimination in a prosecutor's dismissal of jurors who spoke Spanish, arguably because they could not be trusted to listen to the official translation of witnesses who spoke Spanish. Prospective jurors with Latino surnames were also systematically excluded from the jury. As a result, no Latinos served on the jury. ${ }^{15}$

Our inability to recognize discrimination against Latinos is a reflection of our failure to understand the unique historical role that the U.S. has played with each of the distinct cultural groups that make up the Latino diaspora. For example, many Latinos of Mexican and Puerto Rican descent are living with the legacy of being a colonized minority. However, as law Professor Richard Delgado has written: 
"Conquest goes against the American self-concept.

We are not supposed to be a conquering nation, which takes prisoners, enslaves other nations, and steals their territory. That would demand reckoning with. At the same time, it might have given the Latino people today greater insight into their condition. Into the source of their continuing subjugation. Their lack of resources and land. Their political disenfranchisement. The way popular culture demeans and belittles them, despite their history of cultural accomplishment." 16

It is beyond the scope of this policy brief to explain the histories of Latino people, the foreign policy decisions of the U.S. government, or state and local policies and practices that may help explain the overrepresentation of Latino youth in the justice system today. However, we begin with this discussion to remind readers how it can be easier, and more politically palatable, to think of undocumented children as "illegal drug traffickers" rather than refugee children arriving at our borders. We must also recognize how being consistently stigmatized as "illegals" may drive some Latino youth, particularly those youth who are several-generations-native-born, to join gangs in search of the acceptance that their schools, neighborhoods, and country are not providing them. When Latino youth commit delinquent or criminal acts, we should be asking ourselves: Where did the youth learn that behavior? What trauma did he experience in his lifetime? Did she witness violence in her home or neighborhood? Was he victimized in an adult jail or prison? 


\section{DEMOGRAPHICS}

Today, Latinos represent the largest minority group in this country. Approximately 45.5 million Latino people live in the United States, comprising 15\% of the total population. ${ }^{17}$ The demographics of the youth population are also changing rapidly. While Latino youth made up 12\% of the youth population (ages 0 to 17) in the United States in 1990,18 this proportion grew to $21 \%$ in 2007 (see Figure 1). ${ }^{19}$

FIGURE 1: PROPORTION OF LATINO YOUTH IN THE JUVENILE POPULATION AGES 0-17, 200720

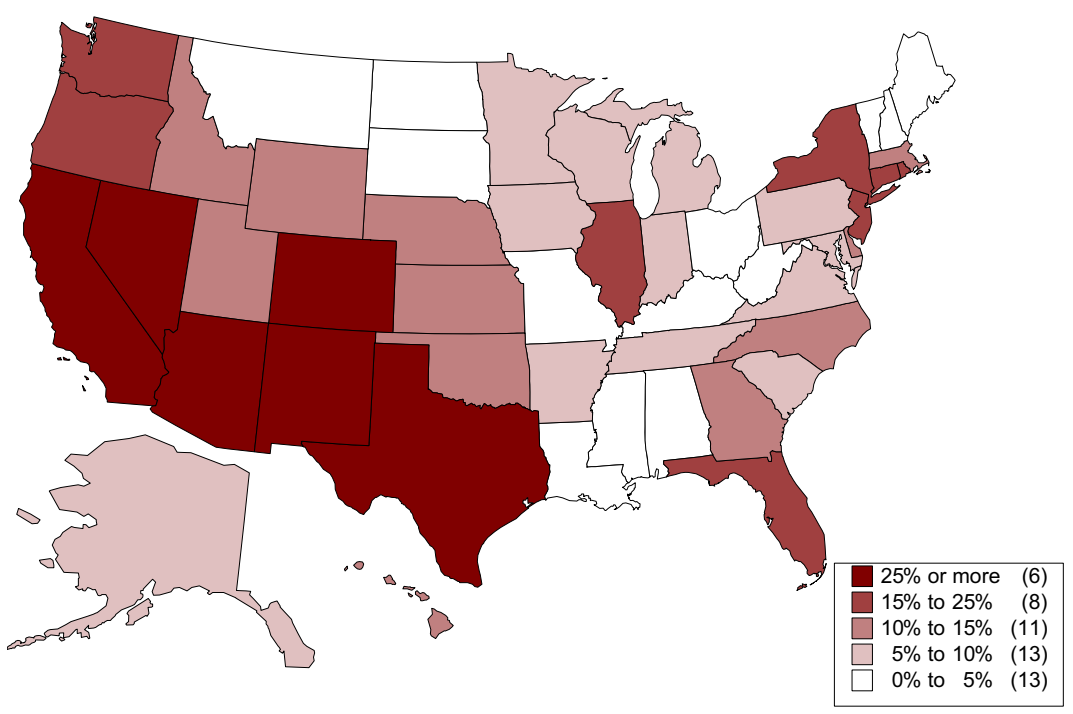


The Latino population is very diverse and its members have varied histories in the U.S., including those of longterm residents and those of more recent immigrants. Latinos are for the most part a mixture of Native Americans and immigrants from Europe, especially from Spain, but many Latinos also have ancestors who were African slaves or Chinese contract laborers. ${ }^{21}$ Some Latinos have ancestors who lived on what is now U.S. territory long before the current borders were set through conquest and land purchases. With the end of the Mexican-American War in 1848, the U.S. annexed a sizeable portion of what is now the western region of the United States: Texas, Arizona, New Mexico, California, Colorado, Nevada, and part of Utah. The Mexicans who decided to stay found themselves to be U.S. citizens and the first Mexican-Americans. ${ }^{22}$ It is therefore not surprising that $64 \%$ of Latinos in the U.S. are of Mexican origin. 23 In addition to long-term residents, many migrant workers and undocumented workers are from Mexico as well.

Puerto Ricans are the second largest group accounting for $9 \%$ of the Latino population in the continental U.S. ${ }^{24}$ Puerto Rico became a colony of the United States at the end of the Spanish-American War in 1898 and Puerto Ricans were the first migrants to arrive to the United States as citizens. ${ }^{25}$ Today, as residents of Puerto Rico, they are still denied the right to vote for the President of the United States.

The third largest group of Latinos in this country is Cubans, who comprise $3.4 \%$ of the Latino population. ${ }^{26}$ The experience of Cuban immigrants to the United States is unique due to their status as political refugees. ${ }^{27}$ 
In recent decades, large numbers of Latinos have been emigrating from countries in South and Central America. ${ }^{28}$ Significant emigration from Central America to the United States began in the 1980s when civil wars in Nicaragua, El Salvador, and Guatemala, combined with already weak economies, created an exodus to the United States. Other periods of increased immigration have followed natural disasters such as Hurricane Mitch in 1998, two earthquakes in El Salvador in 2001, and Hurricane Stan in 2005. ${ }^{29}$

Citizenship and Immigration: The vast majority of Latino children are born in the United States. As of 2007, 90\% of Latinos under age 18 were U.S.-born citizens and an additional $1 \%$ became naturalized citizens. Fewer than $10 \%$ of Latino children were non-citizens. ${ }^{30}$ Although very few Latino children are immigrants, Latino children account for more than half (52\%) of all immigrant youth in the U.S. in 2007. ${ }^{31}$ Many Latino children live in "mixed status" families, those with citizen children and non-citizen parents.

As the result of media campaigns to label persons unauthorized to be in the country as "illegal immigrants," many people believe that most immigrants from Mexico or Latin or South America are undocumented immigrants. However, the latest statistics from the Pew Hispanic Center released in 2009 show that only $4 \%$ of the nation's population are undocumented. ${ }^{32}$ Contrary to popular perceptions, every year millions of people from Mexico and Central and South America are legally admitted to the country, hundreds of thousands are granted legal permanent residence (obtain "green cards") and hundreds of thousands become naturalized citizens, all according to the U.S. Office of Immigration Statistics. ${ }^{33}$ 
Unaccompanied Minors. Each year, more than 80,000 unaccompanied minor children seek entry to the United States. ${ }^{34}$ Many are escaping brutal conditions in their home countries; others may be looking for family members or for new opportunities. ${ }^{35}$ Only a small fraction of these children are allowed to remain in the country. In 2007, the number of unaccompanied children in custody of the federal Office of Refugee Resettlement ranged from approximately 1,000 to 1,600 . Of these, more than $95 \%$ were Latino youth.

\section{IMMIGRANTS, CRIME, AND RACIAL AND ETHNIC PROFILING}

According to Sociologist Robert Sampson, "Among the public, policy makers, and even many academics, a common expectation is that the concentration of immigrants and the influx of foreigners drive up crime rates because of the assumed propensities of these groups to commit crimes and settle in poor, presumably disorganized communities....Yet immigrants appear in general to be less violent than people born in America, particularly when they live in neighborhoods with high numbers of other immigrants." 36

Researchers studied California, the state with the largest undocumented immigrant population to explore the connection between immigration and crime. By examining specific cities in California, including cities known for large gang populations, the researchers found that cities with higher rates of newly arrived immigrants had, if anything, a greater decline in crime rates between 2000 and 2005 than did cities with lower rates of newly arrived 
immigrants. This finding was especially strong for violent crime rates. The researchers concluded that, "Taken together, our findings suggest that spending additional dollars to reduce immigration or to increase enforcement against the foreign-born will not have a high return in terms of public safety." 37

The belief that immigrants are responsible for a significant percentage of crime is part of the justification to allow local law enforcement agencies to enforce civil immigration laws. However, immigration enforcement by local police raises grave concerns about racial and ethnic profiling. The overwhelming majority of Latinos in the U.S. are citizens and legal permanent residents and already have been singled out as a group for immigration stops and inquiries by local law enforcement. ${ }^{38}$ In addition, cities that have been sued for engaging in racial and ethnic profiling in the past, such as the City of Rogers, Arkansas, have been granted permission to enforce immigration law by the U.S. Immigration and Customs Enforcement. These stops reinforce the perception that Latinos are not entitled to full and equal citizenship unless and until proven innocent or "legal."39 


\section{IMMIGRATION CONSEQUENCES OF JUSTICE SYSTEM INVOLVEMENT}

Both juvenile court adjudications and adult court convictions can have serious immigration consequences for all youth who are non-citizens, not just youth who are undocumented. Youth need highly qualified and trained legal counsel to represent them in their delinquency and criminal proceedings so that they fully understand the potential immigration consequences of pleas, admissions, or delinquency findings. Youth also need highly qualified legal counsel in immigration proceedings if their immigration status is compromised.

The crossover between immigration and criminal law is one of the most complex and technical areas of law. Many youth who come into contact with the justice system may unknowingly qualify for a variety of types of legal status including: U.S. citizenship; special immigrant juvenile status (not available to youth prosecuted in the adult criminal justice system); relief under the Violence Against Women Act; special visas if the child has been a victim of serious crime or trafficking; asylum or temporary protected status; or immigration status through family members. ${ }^{40}$ One resource to consult is the Defending Immigrants Partnership, a collaboration among the foremost immigration advocacy and defense organizations (http://defendingimmigrants.org). 


\section{GANGS}

While gang problems are very real for the communities experiencing them, the hysteria surrounding gangs, particularly linked to stereotypes, does little to solve the problem. Under the Bush Administration, the U.S. Immigration and Customs Enforcement (ICE) began Operation Community Shield in 2005, an initiative targeted at transnational gangs and according to their website focused on the "Mara Salvatrucha organization, commonly known as MS-13 [because it is] one of the most violent and rapidly growing transnational street gangs." 41 However, the nonpartisan Congressional Research Service has found that, "despite the gang's reputation, sources in law enforcement indicate that little evidence exists to substantiate that the MS-13 gang is more violent than other street gangs." 42 The perceived threat of gang violence, just like the perceived threat of immigration, has been a tool used to advocate for more money for law enforcement and for stiffer penalties or punishment rather than prevention and intervention programs that would keep youth from joining gangs.

Who are youth gang members? According to the Justice Policy Institute report, Gang Wars, whites make up the largest group of adolescent gang members (40\%). ${ }^{43}$ Yet a 2004 survey of law enforcement agencies estimated that only $8 \%$ of youth gang members were white, almost half (49\%) were Latino, and the remainder (37\%) were African American. ${ }^{44}$ Law enforcement agencies may overestimate the number of Latino gang members in part because they use faulty stereotypes and inappropriately categorize typical adolescent behaviors as "gang" activities. 
Anti-gang laws criminalize the very nature of adolescent behavior. Given the natural tendency for children to associate in peer groups and the research showing that adolescent brains are not developed to resist peer pressure, young people are particularly vulnerable to prosecution under gang-related laws. ${ }^{45}$ Jurisdictions across the country have allowed police to stop and question youth who fit the description of a gang member, and numerous states have gang databases. ${ }^{46}$ As many youth may associate with others who are gang-involved, a significant number of youth could be put into the database in error. A study of Latino youth in California found that $84 \%$ of youth reported having family, friends, or acquaintances in gangs, even though only $10 \%$ of youth personally reported being in a gang or crew themselves. ${ }^{47}$ As police stop groups of youth and photograph them, and a youth does not have to commit a crime to be entered into the database in California, many youth could mistakenly be identified as gang members by mere association and with disastrous legal consequences if they were ever caught for unrelated misbehavior. ${ }^{48}$

Jurisdictions across the country are beginning to realize the mistakes of the arrest and incarcerate strategy. Even Rocky Delgadillo, the Los Angeles city attorney, is now questioning traditional approaches to gangs, even traditional deportation tactics: "In the 1990s, the U.S. strategy centered on deportation. Undocumented gang members convicted of crimes were sent back to their country of origin after their prison sentences. But this only exacerbated the problem..." (Emphasis added). ${ }^{49}$ Some policymakers in Central America believe that U.S. deportation policies "exported" the Los Angeles gang culture to Central 
America and as a result human rights groups report that some 2,000 youth have been killed by vigilante groups in Central America. ${ }^{50}$

Proven responses known to address gang violence and crime are responses that involve the community, parents, youth, religious leaders, service providers, and local law enforcement working together. Los Angeles is now rethinking its approach by using the public health, child development, job development, and community development models that address the major underlying drivers of violence and gang proliferation.51 Similarly, Representatives Robert C. "Bobby" Scott (D-VA) and Mike Castle (R-DE) and Senators Robert Casey (D-PA) and Olympia Snowe (R-ME) have introduced legislation in Congress, the Youth Prison Reduction through Opportunity Mentoring, Intervention, Support and Education (the Youth PROMISE Act, H.R. 1064, S.435, $111^{\text {th }}$ Cong.) to provide federal resources to implement a holistic approach to crime prevention.

\section{LATINO YOUTH IN THE ADULT JUSTICE SYSTEM}

During the 1980s and 1990s, every state enacted "get tough" juvenile policies that made it easier to try youth as adults. ${ }^{52}$ Each year, an estimated 200,000 youth under age 18 are tried as adults in courts nationwide. ${ }^{53}$ As a result of these laws, thousands of Latino youth are prosecuted in the adult criminal justice system every year.

Although the popular slogan "adult time for adult crime" helped pass these laws, the logic upon which it is based is 
faulty. Brain and developmental research has uncovered new developmental differences between adolescents and fully mature adults. We now know that the prefrontal cortex, which governs the "executive functions" of reasoning, advanced thought, and impulse control, is the final area of the human brain to mature, which explains why adolescents have trouble making decisions. ${ }^{54}$ The 2005 U.S. Supreme Court's ruling in Roper v. Simmons abolishing the death penalty for youth under age 18 recognized the validity of this research. Justice Anthony Kennedy wrote, "juveniles are more vulnerable or susceptible [than adults] to negative influences and outside pressures, including peer pressure... This is explained in part by the prevailing circumstance that juveniles have less control, or less experience with control, over their own environment." The opinion also cites scientific and sociological studies on the "underdeveloped sense of responsibility found in youth." 55

When the laws were originally enacted, policymakers did not have complete information about the adolescent brain research or about the harmful impact of these laws. However, since the 1980s and 90s, considerable research has been done to document the harm to both the youth and the general public as a result of these laws.

In 2007, the U.S. Centers for Disease Control and Prevention's Task Force on Community Preventive Services found that youth who are tried as adults are, on average, $34 \%$ more likely to commit crimes than youth retained in the juvenile justice system. The Task Force also found that transfer to the adult criminal justice system 
typically increases rather than decreases rates of violence among transferred youth. As a result, the Task Force recommended against "laws or policies facilitating the transfer of juveniles from the juvenile to the adult judicial system." 56

The following year in August 2008, the Office of Juvenile Justice and Delinquency Prevention, the federal agency dedicated to juvenile justice issues at the U.S. Department of Justice, released Juvenile Transfer Laws: An Effective Deterrent to Delinquency?, a bulletin that found that laws making it easier to transfer youth to the adult criminal court system have little or no general deterrent effect on crime (i.e., transfer laws do not prevent youth from engaging in criminal behavior). On the contrary, the bulletin also found that youth transferred to the adult system are more likely to be rearrested and to reoffend than are youth who committed similar crimes but were retained in the juvenile justice system. According to the bulletin, higher recidivism rates are due to a number of factors, including:

- Stigma from being labeled as a convicted felon;

- Sense of resentment and injustice about being tried as an adult;

- Learning more criminal behavior while incarcerated with adults;

- Decreased access to rehabilitation and family support in the adult system; and

- Decreased employment and community integration opportunities due to a felony conviction. 57 
When Latino youth are prosecuted in the adult system, they are deprived of rehabilitative opportunities, including education, mental health services, and other age-appropriate services that make it more likely that the youth will become a law-abiding, productive citizen. In addition, Latino youth prosecuted in the adult system can be held in adult jails and prisons where they are at great risk of suicide and sexual assault. ${ }^{58}$

\section{Difficulties Completing EducAtion}

Latino youth who are prosecuted in the adult criminal justice system have a very difficult time completing their education. Latino youth as a group are already the most likely group to be out of school and without a high school diploma between the ages of 16 and 24 (see Figure 2).59 Many more white students (78\%) than Latino students (58\%) graduate with a regular high school diploma within four years. ${ }^{60}$ In 2007, 40\% of Latinos ages 25 and older were not high school graduates, compared to $14 \%$ of whites and $18 \%$ of African Americans. ${ }^{61}$ For Latino youth involved in the justice system, additional barriers to education only increase the likelihood that they will not complete their education. 
FIGURE 2: PERCENT OF YOUTH AGES 16-24 WHO ARE NOT IN SCHOOL AND HAVE NOT EARNED A HIGH SCHOOL DIPLOMA OR EQUIVALENCY CREDENTIAL, 1972-200562

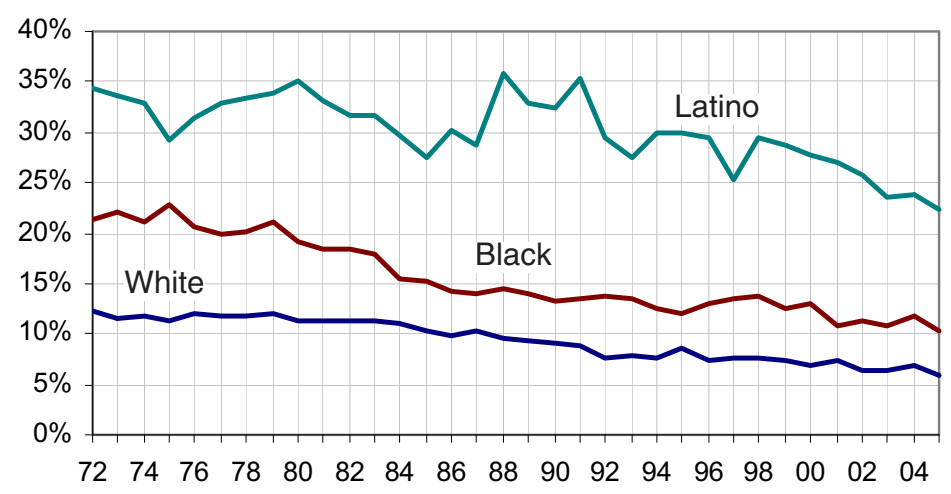

Many youth who are tried in the adult system are held in adult jails. The most recent survey of educational programs in adult jails found that $40 \%$ of jails provided no educational services at all, only $11 \%$ provided special education services, and just $7 \%$ provided vocational training. ${ }^{63}$ Because of their age, most youth in jails have not completed their high school education and need classes to graduate or obtain a GED or to acquire vocational skills to get a job.

The educational neglect of youth in adult jails is not only harmful to Latino youth, but it also has consequences for public safety. Rather than prosecuting and incarcerating Latino youth in the adult justice system, efforts should be made to connect these young people to programs and services that will improve their education and employment prospects. While transferring youth to the adult system increases recidivism and therefore increases crime, economists have calculated that each Latino male who graduates 
from high school is associated with a savings to the criminal justice system of more than $\$ 38,300$ (the estimate accounts for the expense of trials, sentencing, and incarceration). ${ }^{64}$

\section{DifFiculties Gaining EMPLOYMENT}

Latino youth who have contact with the criminal justice system face significant barriers to obtaining stable employment. Most states allow employers to deny jobs to anyone with a criminal record. ${ }^{65}$ In fact, in most states employers can deny jobs to people who were arrested but never convicted of a crime. One study of employers found that more than $60 \%$ of employers probably would not hire an applicant with a criminal record. ${ }^{66}$ Employers in a growing number of professions, including home health care, nursing, education, eyeglass dispensing, plumbing, and even barbering, are barred by state licensing agencies from hiring people with a wide range of criminal convictions, even convictions that are unrelated to the job or license sought. 67

There are long-term economic consequences of adult court prosecution for the Latino community as a whole. Despite the fact that Latinos have the highest labor force participation rate of any group, Latino families report the lowest levels of economic security. According to a 2008 Rockefeller Foundation/TIME Magazine survey conducted before the current economic crisis, 39\% of Latinos were very worried about their family's economic security, versus $24 \%$ of whites and $38 \%$ of African Americans who felt this way. ${ }^{68}$ 
Low wages and uncertain employment status are major contributors to family economic insecurity. In 2006, more than one-third (37\%) of Latino children lived in a family in which neither parent had full-time, yearround employment, versus only one-quarter of white children who lived in this kind of family. ${ }^{69}$ Lack of job security among Latinos is partially due to their overrepresentation in nontraditional, often short-term work arrangements such as independent contractors and on-call workers. The lack of stable employment opportunities for young Latinos involved in the justice system and their families substantially increases their further risk of exposure to the justice system by encouraging participation in the illicit economy as well as by making Latino youth and families vulnerable to abusive labor practices.

\section{NATIONAL ARREST STATISTICS}

National arrest information for Latino youth has never been easy to obtain. The most extensive data set on youth arrests, the FBI's Crime in the United States report, does not keep data for Latino youth. ${ }^{70}$ Although not a complete picture of Latino arrests, the National Center on Juvenile Justice (NCJJ) has recently analyzed data from the National Incident Based Reporting System (NIBRS), a reporting system for crimes known to the police, to gain some initial insight into Latino youth offending and police enforcement. ${ }^{71}$

An important finding from that analysis is that timeof-day arrest patterns appear to be consistent for all races and ethnicities. Latino youth, like African- 
American and white youth, are arrested most during the peak afterschool hours between 3:00 and 4:00 PM, declining throughout the evening (see Figure 3). ${ }^{72}$ In contrast, Latino adults are most likely to be arrested at night (see Figure 4). ${ }^{73}$

FIGURE 3: JUVENILE ARRESTEES: TIME OF DAY DISTRIBUTION BY RACE/ETHNICITY GROUP74

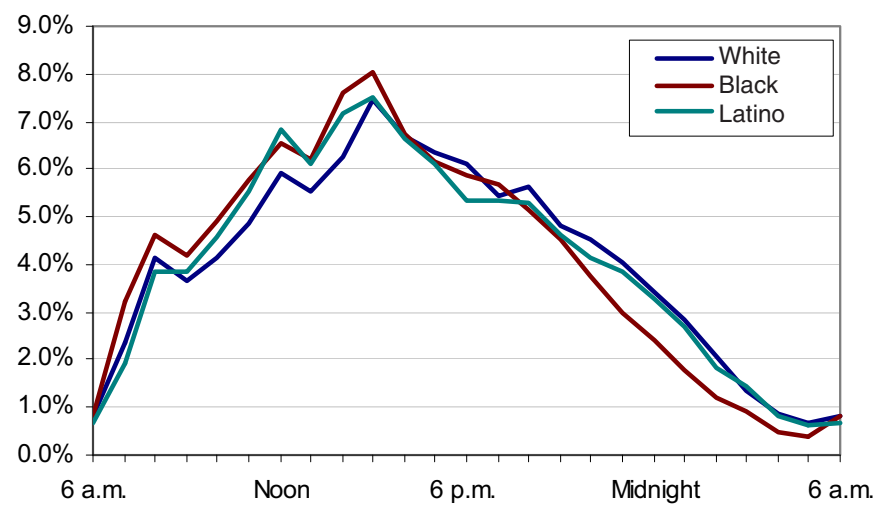

FIGURE 4: LATINO ARRESTEES: TIME OF DAY DISTRIBUTION BY AGE GROUP75

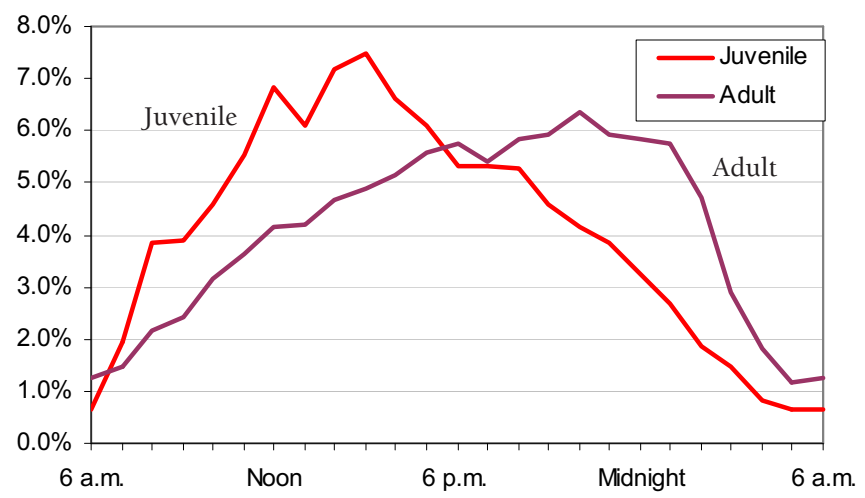


FIGURE 5: LATINO ARRESTEES: TIME OF DAY DISTRIBUTION BY AGE GROUP, ASSAULT OFFENSES 76

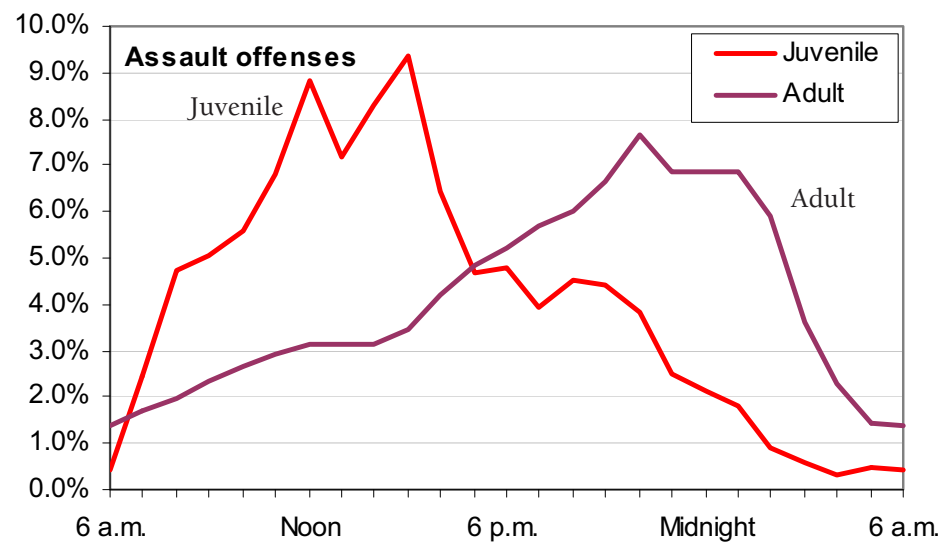

NCJJ also conducted an analysis of assault offenses, finding that Latino youth are more likely than Latino adults to be arrested during traditional school hours. The spike during the noon hour is particularly intriguing (see Figure 5). ${ }^{77}$ The young people arrested may have been out of school, or these may have been school-related arrests.

\section{California and Arizona Arrest Statistics}

Two states that have significant Latino populations and disaggregate their arrest data by race and ethnicity are California and Arizona. Examining the arrest data for Latino youth in these two states provides another window into the characteristics of Latino youth offending.

In both California and Arizona, one out of every five Latinos arrested is a youth (19\%). In both states, 
although Latino youth account for less than $10 \%$ of total arrests in each state (8\% in California, 6\% in Arizona), they make up a large proportion of the youth who are arrested in each state $(51 \%$ of youth arrested in California, 38\% of youth in Arizona). ${ }^{78}$

\section{TABLE 1: LATINO JUVENILE ARRESTEES FOR SELECTED OFFENSES, $2007^{79}$}

\begin{tabular}{|l|c|c|}
\hline & $\begin{array}{c}\text { California } \\
\%\end{array}$ & $\begin{array}{c}\text { Arizona } \\
\%\end{array}$ \\
\hline Latino youth in the population (10-17,2007) & 46 & 39 \\
\hline Latino youth arrests as a proportion of all youth arrests & 51 & 38 \\
\hline $\begin{array}{l}\text { Latino youth arrests as a proportion of total arrests } \\
\text { (includes arrests of adults and youth of any race or ethnic group) }\end{array}$ & 8 & 6 \\
\hline Latino youth arrests as a proportion of all Latino arrests & 19 & 19 \\
\hline $\begin{array}{l}\text { Proportion of Latino youth arrests for the crimes of murder, } \\
\text { manslaughter, rape, or robbery }\end{array}$ & 2 & 1 \\
\hline
\end{tabular}

Although Latino youth have a dangerous and violent image, as we see in Table 1, relatively few youth are arrested for the most serious crimes of murder, manslaughter, rape, or robbery. In California, 2\% of Latino youth arrests are for these serious crimes; in Arizona, $1 \%$ are arrested for these serious crimes. 80 The perception that Latino youth are really dangerous, in contrast to the reality that Latino youth are similar to all other youth, may explain why Latino youth receive the most punitive treatment in the justice system.

What are the majority of Latino youth arrested for? In the state of California, the top five crimes for which Latino youth are arrested, accounting for $40 \%$ of all Latino youth arrests, are for curfew violations (11\%), assault/battery (9\%), petty theft (8\%), vandalism (6\%), and marijuana (6\%). ${ }^{81}$ In the state of Arizona, more than $50 \%$ of Latino youth are arrested for the top 
five crimes of larceny-theft (14\%), running away $(10 \%)$, curfew/loitering violations (10\%), liquor law violations (9\%), and simple assault (9\%). 82

\section{NATIONAL JUVENILE COURT PROCESSING STATISTICS}

After arrest, a youth may be referred to juvenile court where a charge may be dismissed or handled informally, or a petition may be filed in the juvenile court for formal intervention. The National Center on Juvenile Justice (NCJJ) analyzed data from the National Juvenile Court Data Archive and found that almost 150,000 cases involving Latino youth were handled by juvenile courts across the country in 2005 (see Table 2 ). Because only 13 of the 42 jurisdictions reporting to the Archive consistently reported ethnicity data, accounting for nearly two-thirds (63\%) of the nation's Latino youth population, the number of cases is a significant undercount. 83

TABLE 2: LATINO YOUTH JUVENILE COURT CASE PROCESSING, $2005^{88}$

\begin{tabular}{|l|c|c|c|c|c|}
\hline & $\begin{array}{c}\text { All } \\
\text { Delinquency } \\
\text { Cases }\end{array}$ & Person & Property & Drugs & $\begin{array}{c}\text { Public } \\
\text { Order }\end{array}$ \\
\hline Number of Cases & 149,468 & 30,770 & 49,205 & 19,652 & 49,841 \\
\hline Non Petitioned & $44 \%$ & $41 \%$ & $48 \%$ & $47 \%$ & $42 \%$ \\
\hline Petitioned & $56 \%$ & $59 \%$ & $52 \%$ & $53 \%$ & $58 \%$ \\
\hline Waived to Adult System & $1.0 \%$ & $2.4 \%$ & $0.7 \%$ & $0.9 \%$ & $0.4 \%$ \\
\hline \multicolumn{1}{|c|}{ Adjudicated } & $78 \%$ & $75 \%$ & $78 \%$ & $80 \%$ & $79 \%$ \\
\hline Not Adjudicated & $21 \%$ & $23 \%$ & $21 \%$ & $19 \%$ & $20 \%$ \\
\hline Adjudicated & & & & & \\
\hline Placed & $24 \%$ & $27 \%$ & $22 \%$ & $20 \%$ & $26 \%$ \\
\hline Probation & $66 \%$ & $65 \%$ & $68 \%$ & $70 \%$ & $64 \%$ \\
\hline Detention & $23 \%$ & $30 \%$ & $17 \%$ & $18 \%$ & $26 \%$ \\
\hline
\end{tabular}


According to the NCJJ analysis, Latino youth accounted for $29 \%$ of the juvenile ( 0 to 17 ) population in these states; a similar proportion (27\%) of delinquency cases handled in these states involved Latino youth. ${ }^{84}$ Slightly more than half $(56 \%)$ of the cases were petitioned, and of those, more than three-quarters (78\%) of Latino youth were adjudicated delinquent ("found guilty"). 85

We calculated a ratio, known as a relative rate index (RRI), to identify precisely which justice system contact points contain disparities (see Table 3). ${ }^{86}$ An RRI that is greater than 1 indicates that Latino youth are more likely than white youth to be at that contact point; an RRI of less than 1 indicates that Latino youth are less likely than white youth to be at that contact point. In order of rising disparities, Latino youth are:

- $4 \%$ more likely than white youth to be petitioned;

- $16 \%$ more likely than white youth to be adjudicated delinquent;

- $28 \%$ more likely than white youth to be detained;

- $41 \%$ more likely than white youth to receive an out-of-home placement; and

- $43 \%$ more likely than white youth to be waived to the adult system. ${ }^{87}$ 
TABLE 3: LATINO/WHITE RATIOS (RRIs) FOR JUVENILE COURT CASE PROCESSING BY TYPE OF OFFENSE, $2005^{89}$

\begin{tabular}{|l|c|c|c|c|c|}
\hline & $\begin{array}{c}\text { All } \\
\text { Delinquency } \\
\text { Cases }\end{array}$ & Person & Property & Drug & $\begin{array}{c}\text { Public } \\
\text { Order }\end{array}$ \\
\hline Non Petitioned & 0.96 & 0.89 & 0.94 & 0.96 & 1.11 \\
\hline Petitioned & 1.04 & 1.09 & 1.06 & 1.04 & 0.94 \\
\hline Waived to Adult System & 1.43 & 1.85 & 1.00 & 1.00 & 2.00 \\
\hline Adjudicated & 1.16 & 1.23 & 1.16 & 1.23 & 1.11 \\
\hline Not Adjudicated & 0.64 & 0.61 & 0.66 & 0.56 & 0.69 \\
\hline Adjudicated & & & & & \\
\hline Placed & 1.41 & 1.50 & 1.47 & 1.82 & 1.37 \\
\hline$\quad$ Probation & 1.06 & 1.00 & 1.03 & 1.01 & 1.19 \\
\hline Detention & 1.28 & 1.30 & 1.31 & 1.38 & 1.04 \\
\hline
\end{tabular}

\section{LANGUAGE}

"In the 1940s, as still seen today, increasing arrests of youth of color led to an overrepresentation of Latinos in Los Angeles detention facilities. Then, [Spanishspeaking] youth serving time at the California State Reform School in Whittier were given a battery of tests in English. Based on the results, school officials labeled more than 60 percent of Latino youth as 'feeble-minded' or 'unable to develop beyond the intellectual level of an average 12-year-old.' Not surprisingly, Latino wards were responsible for the greatest percentage of escapes from the institution. "90

The justice system often fails to meet the linguistic needs of Latino children and families. While a large majority of Latino children speak English only (31\%) or speak English very well (50\%), approximately one in five Latino children (18\%) speak English less than very well. ${ }^{91}$ In contrast, many of their parents do not speak English very well. Roughly one-fifth (22\%) of 
Latino public-school children, a similar population to youth in the justice system, live in linguistically isolated homes, meaning that no person age 14 or over in the household speaks English very well. ${ }^{91}$

Another myth about Latinos is that they don't want to learn English. Latinos generally, and 92\% of Spanish-dominant Latinos, believe that English is necessary for success in the U.S. ${ }^{93}$ However, many families may not have acquired the English language skills by the time they or their children have had contact with the justice system. Furthermore, the justice system itself has an entirely new vocabulary (e.g., adjudication, conviction, adjustment, disposition) that many families, regardless of their English-language skills, find intimidating and unfamiliar.

Title VI of the Civil Rights Act of 1964 guarantees that no program that receives any federal assistance, no matter how small, can exclude anyone based on race or national origin. Programs and activities must be available and accessible to those who have limited English proficiency, including translation if necessary. ${ }^{94}$ Justice systems should ensure that linguistic barriers are not the cause of disparities in the system.

A report by the Vera Institute of Justice, If Parents Don't Speak English Well, Will Their Kids Get Locked $U p$ ?, found that language barriers did impact the treatment of youth. For example:

- A police officer may leave a child overnight in a detention center because the parents cannot speak English and respond to questions. 
- Parents who cannot read court documents that are only available in English may not appear for important meetings and hearings during which decisions to detain or incarcerate their children take place.

- A parent's limited English proficiency may prevent him or her from understanding the court terminology, and the youth's case may be prosecuted instead of resolved through an alternative dispute resolution process.

- A probation officer or health care clinician asked to determine whether a parent is capable of supervising a child may recommend that a minor be sentenced to a state-run correctional facility because an interpreter did not accurately translate the parent's response. ${ }^{95}$

Sometimes justice system professionals ask the child to serve as the primary intermediary between family members and professionals. This role can create conflicts by undermining parental authority and damaging a parent's ability to make decisions for his or her child and should be avoided. ${ }^{96}$

Latino youth with limited English proficiency who are in detention or correctional facilities are particularly vulnerable. An investigation of the Los Angeles County Juvenile Halls by the U.S. Department of Justice revealed that youth who only spoke Spanish generally had not received sufficient orientation to understand how to access essential services such as medical or mental health care if they needed them. Youth who did not speak English had a harder time receiving necessary evaluations and care. ${ }^{97}$ 


\section{OVERINCARCERATION OF YOUTH IN JUVENILE FACILITIES}

The Census of Juveniles in Residential Placement (CJRP) is a one-day count of all the juvenile offenders held in residential placement throughout the United States and it is one national data set of youth involved in the juvenile justice system that collects comprehensive ethnicity data. ${ }^{98}$ A variety of types of facilities are covered in the census. On the day of the 2006 census, $39 \%$ of the Latino youth in residential placement were incarcerated in detention centers, 32\% were incarcerated in long-term secure facilities, $20 \%$ were held in group homes, and the remaining $10 \%$ were held in reception/diagnostic centers, boot camps, shelters, and ranch/wilderness camps. ${ }^{99}$ Roughly one-third of the youth were held in the facilities on a detained ("pretrial") status and two-thirds were held on a committed ("post-trial") status. 100

States with proportionally more Latinos in placement tend to be in the Southwest and New York metro area (see Figure 6). 101 
FIGURE 6: LATINO PROPORTION OF JUVENILE OFFENDERS IN RESIDENTIAL PLACEMENT ${ }^{102}$

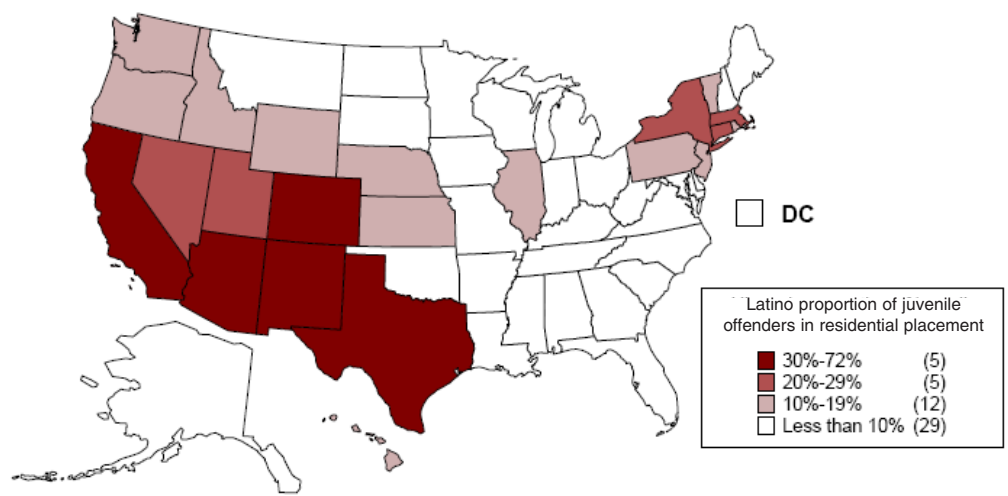

The placement rate for Latino juveniles varied by state from 0 to 1,139 per 100,000 (see Figure 7). ${ }^{103}$

FIGURE 7: LATINO JUVENILES IN PLACEMENT PER 100,000 IN POPULATION104

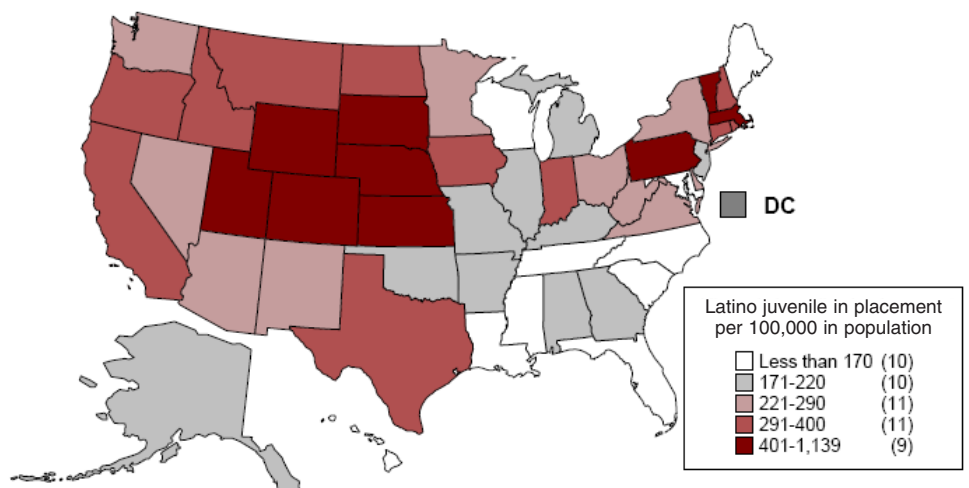


In the five states of Vermont, Massachusetts, Connecticut, Pennsylvania, and Hawaii, the placement rate for Latinos was more than four times the rate for non-Latino whites (See Figure 8). 105

\section{FIGURE 8: RATIO OF LATINO RATE OF PLACEMENT TO WHITE NON-LATINO RATE OF PLACEMENT106}

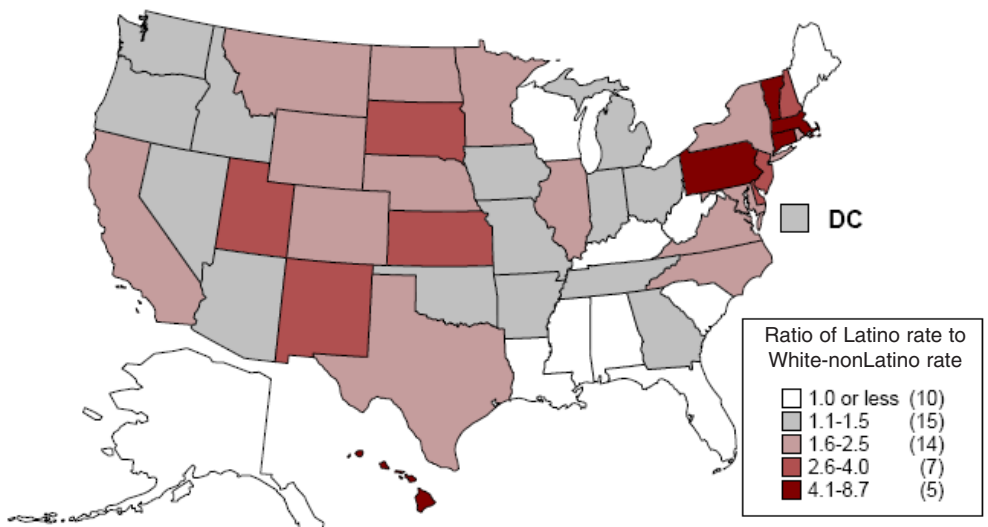

Latino Youth in Detention Centers

According to best practice standards, the only acceptable purposes for the detention of youth are: 1) to ensure youth are present for court hearings; 2) to protect public safety by preventing the youth from committing more serious crimes while awaiting trial; or 3) to hold youth pursuant to a specific court order for detention. ${ }^{107}$ The public's desire to punish youth should not play a role in whether a youth is detained pre-trial because prior to the resolution of the case, the youth has not been found guilty. Many youth who are not a risk to public safety, but have unmet needs, are 
also often detained. These youth also should not be detained, but are more appropriately served in community-based programs.

According to data from the CJRP, however, evidence suggests that many Latino youth are unnecessarily detained before trial. Of Latino youth incarcerated in detention centers, more than $70 \%$ are charged with non-violent offenses and nearly $30 \%$ are charged with technical violations of probation, parole, or court orders. 108

\section{Youth Committed to Residential Placement}

After a youth has been adjudicated (i.e., found guilty), the court develops a "disposition" (the equivalent to an adult court "sentence") to identify the necessary services and sanctions for the child to be rehabilitated. Possible dispositions for delinquent youth range from the most severe punishment of incarceration in a youth correctional facility to placement in other non-secure residential facilities such as group homes or treatment facilities, or lesser sanctions such as probation, fines, restitution, or community service. The vast majority of delinquency cases do not result in an incarceration sentence or out-of-home placement; according to the National Center for Juvenile Justice, only $24 \%$ of adjudicated Latino youth were removed from their homes in 2005. ${ }^{109}$ However, Latino youth are $40 \%$ more likely than white youth to be removed from their homes and placed in a residential facility, 110 and they are nearly twice as likely to be placed out of their homes for a drug offense. ${ }^{111}$ 
The majority of Latino youth who were placed outside of their homes (e.g., secure facility, residential treatment facility, or group home) were not held for violent offenses. In 2006, 65\% of committed Latino youth had been found guilty of non-violent offenses, including 28\% committed for property offenses, $9 \%$ for drug offenses, $11 \%$ for public order offenses, $15 \%$ for technical violations, and $2 \%$ for status offenses. Even among Latinos committed to long-term secure incarceration, more than half were charged with nonviolent offenses. ${ }^{112}$

When Latinos are committed, they are more than $70 \%$ more likely than whites to be committed to facilities of 200 or more residents. Latinos are 19\% more likely to be committed to a long-term secure center and $38 \%$ more likely to be committed to a detention center. In contrast, white youth are more than 50\% more likely to be committed to a group home and more than three times as likely to be committed to a shelter. ${ }^{113}$

\section{PATHWAYS TO ADULT COURT}

There are three primary ways children are sent to adult court. Forty-six states have judicial waiver, the traditional path to the adult system wherein a juvenile court judge makes a decision to transfer a youth's case to adult court after considering several factors such as age, offense, and services available in the juvenile system. ${ }^{114}$ In contrast to a judicial decisionmaker, the prosecutorial discretion transfer mechanism, also known as direct file in some states, allows the prose- 
cutor a choice between filing the case in juvenile or adult court, usually depending on cases that meet certain offense or offender criteria. Fifteen states grant prosecutors full discretion to decide whether certain cases will be tried in the adult system. ${ }^{115}$ Finally, statutory exclusion, also known as automatic waiver or legislative waiver, provisions expressly prohibit the juvenile court from hearing certain types of cases. For example, 13 states currently require all youth ages 16 or 17 , depending on the state, to be tried in the adult criminal system regardless of how minor the offense. 116 Twenty-nine states have mandatory transfer policies for certain violent offenses. ${ }^{117}$ Thirty-four states have "once an adult, always an adult" provisions requiring that youth who have been tried or convicted as adults be prosecuted in the adult system for any subsequent offense. ${ }^{118}$

Although there is no national data system that collects data on youth transferred to the adult system, researchers estimate that as many as 200,000 youth are prosecuted as adults each year. ${ }^{119}$ Latinos are more than $40 \%$ more likely than white youth to be waived to the adult criminal justice system and nearly twice as likely to be waived for a person offense. ${ }^{120}$ However, these statistics significantly underestimate the numbers of youth transferred to the adult system because judicial waiver represents a small portion of youth tried as adults.

A significant percentage of Latino youth are at risk of being tried as adults or are being held in an adult jail by virtue of where they live (see Table 4 ). 
- More than one-third (37\%) of Latino youth ages 10 to 17 live in one of the 13 states where the maximum age of juvenile jurisdiction is 16 or 17 , in contrast to the majority of the country where juvenile jurisdiction ends at the 18th birthday. In these 13 states, regardless of how minor the crime the child commits, the case will automatically be prosecuted in the adult criminal justice system. ${ }^{121}$

- Half (50\%) of all Latino youth ages 10 to 17 live in a state where the prosecutor has the discretion to directly file some cases in the adult criminal court. ${ }^{121}$

- More than two-thirds (69\%) of Latino youth ages 10 to 17 live in a state with statutes that exclude certain offenses from juvenile court jurisdiction. In those states, youth charged with specified offenses automatically end up in the adult system. ${ }^{121}$

- Nine out of ten (89\%) Latino youth ages 10 to 17 live in a state where juvenile court judges are authorized to waive some cases to the adult criminal courts. ${ }^{124}$ 
TABLE 4: LATINO YOUTH POPULATIONS AND TRANSFER LAWS BY STATE AS OF 2007 LEGISLATIVE SESSION 125

\begin{tabular}{|c|c|c|c|}
\hline & $\begin{array}{l}\text { Latino Population } \\
\text { Ages 10-17 }\end{array}$ & $\begin{array}{l}\text { Latinos as Percentage of } \\
\text { Total 10-17 Population in State }\end{array}$ & $\begin{array}{l}\text { Age of Juvenile } \\
\text { Jurisdiction }\end{array}$ \\
\hline Alabama & 16,000 & $3 \%$ & 18 \\
\hline Alaska & 5,000 & $6 \%$ & 18 \\
\hline Arizona & 281,000 & $39 \%$ & 18 \\
\hline Arkansas & 21,000 & $7 \%$ & 18 \\
\hline California & $1,980,000$ & $46 \%$ & 18 \\
\hline Colorado & 132,000 & $25 \%$ & 18 \\
\hline Connecticut & 57,000 & $15 \%$ & $16^{*}$ \\
\hline Delaware & 8,000 & $8 \%$ & 18 \\
\hline District of Columbia & 4,000 & $8 \%$ & 18 \\
\hline Florida & 407,000 & $22 \%$ & 18 \\
\hline Georgia & 87,000 & $8 \%$ & 17 \\
\hline Hawaii & 14,000 & $11 \%$ & 18 \\
\hline Idaho & 24,000 & $14 \%$ & 18 \\
\hline Illinois & 265,000 & $18 \%$ & $17^{*}$ \\
\hline Indiana & 43,000 & $6 \%$ & 18 \\
\hline Iowa & 18,000 & $6 \%$ & 18 \\
\hline Kansas & 37,000 & $12 \%$ & 18 \\
\hline Kentucky & 12,000 & $3 \%$ & 18 \\
\hline Louisiana & 16,000 & $3 \%$ & 17 \\
\hline Maine & 2,000 & $2 \%$ & 18 \\
\hline Maryland & 42,000 & $7 \%$ & 18 \\
\hline Massachusetts & 77,000 & $11 \%$ & 17 \\
\hline Michigan & 60,000 & $5 \%$ & 17 \\
\hline Minnesota & 30,000 & $5 \%$ & 18 \\
\hline Mississippi & 8,000 & $2 \%$ & 18 \\
\hline Missouri & 25,000 & $4 \%$ & 17 \\
\hline Montana & 4,000 & $4 \%$ & 18 \\
\hline Nebraska & 20,000 & $10 \%$ & 18 \\
\hline Nevada & 96,000 & $34 \%$ & 18 \\
\hline New Hampshire & 5,000 & $3 \%$ & 17 \\
\hline New Jersey & 165,000 & $17 \%$ & 18 \\
\hline New Mexico & 117,000 & $53 \%$ & 18 \\
\hline New York & 394,000 & $19 \%$ & 16 \\
\hline North Carolina & 76,000 & $8 \%$ & 16 \\
\hline North Dakota & 2,000 & $3 \%$ & 18 \\
\hline Ohio & 41,000 & $3 \%$ & 18 \\
\hline Oklahoma & 38,000 & $10 \%$ & 18 \\
\hline Oregon & 60,000 & $15 \%$ & 18 \\
\hline Pennsylvania & 84,000 & $6 \%$ & 18 \\
\hline Rhode Island & 18,000 & $17 \%$ & 18 \\
\hline South Carolina & 19,000 & $4 \%$ & 17 \\
\hline South Dakota & 3,000 & $3 \%$ & 18 \\
\hline Tennessee & 25,000 & $4 \%$ & 18 \\
\hline Texas & $1,198,000$ & $43 \%$ & 17 \\
\hline Utah & 45,000 & $14 \%$ & 18 \\
\hline Vermont & 1,000 & $2 \%$ & 18 \\
\hline Virginia & 58,000 & $7 \%$ & 18 \\
\hline Washington & 93,000 & $13 \%$ & 18 \\
\hline West Virginia & 3,000 & $2 \%$ & 18 \\
\hline Wisconsin & 40,000 & $7 \%$ & 17 \\
\hline Wyoming & 6,000 & $10 \%$ & 18 \\
\hline
\end{tabular}

${ }^{*}$ CT passed Public Act 07-4 in 2007 to raise the age of juvenile jurisdiction to 18 in 2010. IL passed Public Act 95-1031 in 2009 to allow 17-year-old misdemeanants to be tried in the juvenile courts. 


\begin{tabular}{|c|c|c|c|c|}
\hline $\begin{array}{l}\text { Judicial Waiver } \\
\text { State }\end{array}$ & $\begin{array}{c}\text { Prosecutorial } \\
\text { Discretion State }\end{array}$ & $\begin{array}{c}\text { Statutory Exclusion } \\
\text { State }\end{array}$ & $\begin{array}{l}\text { Mandates Pre-Trial } \\
\text { Detention in Adult Jails }\end{array}$ & $\begin{array}{l}\text { Permits Pre-Trial } \\
\text { Detention in Adult Jails }\end{array}$ \\
\hline $\mathrm{x}$ & & $\mathrm{x}$ & $x$ & \\
\hline $\mathrm{x}$ & & $\mathrm{x}$ & $\mathrm{x}$ & $\mathrm{x}$ \\
\hline $\mathrm{x}$ & $\mathrm{x}$ & $\mathrm{x}$ & & $\mathrm{x}$ \\
\hline $\mathrm{x}$ & $\mathrm{x}$ & & & $\mathrm{x}$ \\
\hline $\mathrm{x}$ & $\mathrm{x}$ & $\mathrm{x}$ & & $\mathrm{x}$ \\
\hline \multirow[t]{2}{*}{$x$} & $\mathrm{x}$ & & & $\mathrm{x}$ \\
\hline & & & $\mathrm{x}$ & \\
\hline $\mathrm{x}$ & & $\mathrm{x}$ & $\mathrm{x}$ & \\
\hline $\mathrm{x}$ & $\mathrm{x}$ & & & $\mathrm{x}$ \\
\hline $\mathrm{x}$ & $\mathrm{x}$ & $\mathrm{x}$ & $\mathrm{x}$ & \\
\hline $\mathrm{x}$ & $\mathrm{x}$ & $\mathrm{x}$ & & $\mathrm{x}$ \\
\hline $\mathrm{x}$ & & & $\mathrm{x}$ & \\
\hline $\mathrm{x}$ & & $\mathrm{x}$ & & $\mathrm{x}$ \\
\hline $\mathrm{x}$ & 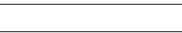 & $\mathrm{x}$ & 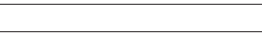 & $\mathrm{x}$ \\
\hline $\mathrm{x}$ & & $\mathrm{x}$ & & $\mathrm{x}$ \\
\hline $\mathrm{x}$ & & $\mathrm{x}$ & & $\mathrm{x}$ \\
\hline $\mathrm{x}$ & & & & $\mathrm{x}$ \\
\hline \multicolumn{5}{|l|}{$\mathrm{x}$} \\
\hline $\mathrm{x}$ & $\mathrm{x}$ & $\mathrm{x}$ & $\mathrm{x}$ & \\
\hline $\mathrm{x}$ & & & & $\mathrm{x}$ \\
\hline \multirow[t]{2}{*}{$\mathrm{x}$} & & $\mathrm{x}$ & $\mathrm{x}$ & \\
\hline & & $\mathrm{x}$ & & $\mathrm{x}$ \\
\hline $\mathrm{x}$ & $\mathrm{x}$ & & & $\mathrm{x}$ \\
\hline $\mathrm{x}$ & & $\mathrm{x}$ & & $\mathrm{x}$ \\
\hline $\mathrm{x}$ & & $\mathrm{x}$ & & $\mathrm{x}$ \\
\hline \multirow[t]{3}{*}{$x$} & & & & $\mathrm{x}$ \\
\hline & $\mathrm{x}$ & $\mathrm{x}$ & & $\mathrm{x}$ \\
\hline & $\mathrm{x}$ & & & $\mathrm{x}$ \\
\hline $\mathrm{x}$ & & $\mathrm{x}$ & 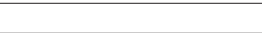 & $\mathrm{x}$ \\
\hline $\mathrm{x}$ & & & $\mathrm{x}$ & \\
\hline \multirow[t]{3}{*}{$\mathrm{x}$} & & & & $x$ \\
\hline & & $\mathrm{x}$ & & $\mathrm{x}$ \\
\hline & & $\mathrm{x}$ & & $\mathrm{x}$ \\
\hline $\mathrm{x}$ & & & & $\mathrm{x}$ \\
\hline $\mathrm{x}$ & & & & $\mathrm{x}$ \\
\hline $\mathrm{x}$ & & & & $\mathrm{x}$ \\
\hline $\mathrm{x}$ & $\mathrm{x}$ & $x$ & $\mathrm{x}$ & \\
\hline $\mathrm{x}$ & & $\mathrm{x}$ & & $\mathrm{x}$ \\
\hline $\mathrm{x}$ & & $\mathrm{x}$ & & $\mathrm{x}$ \\
\hline $\mathrm{x}$ & & & & $\mathrm{x}$ \\
\hline $\mathrm{x}$ & & $\mathrm{x}$ & & $\mathrm{x}$ \\
\hline$x$ & & $\mathrm{x}$ & & $x$ \\
\hline $\mathrm{x}$ & & & & $\mathrm{x}$ \\
\hline $\mathrm{x}$ & & & & $\mathrm{x}$ \\
\hline $\mathrm{x}$ & & $\mathrm{x}$ & & $x$ \\
\hline $\mathrm{x}$ & $\mathrm{x}$ & $\mathrm{x}$ & & $x$ \\
\hline$x$ & $x$ & & & $\mathrm{x}$ \\
\hline $\mathrm{x}$ & & $\mathrm{x}$ & & $x$ \\
\hline \multicolumn{5}{|l|}{$\mathrm{x}$} \\
\hline $\mathrm{x}$ & & $\mathrm{x}$ & & $\mathrm{x}$ \\
\hline $\mathrm{x}$ & $\mathrm{x}$ & & & \\
\hline
\end{tabular}


Some states provide data that allow us to examine the contact that Latino youth have with the adult criminal justice system.

\section{CALIFORNIA}

Since March 7, 2000, when California voters passed a ballot initiative, Proposition 21, the "Gang Violence and Juvenile Crime Prevention Act of 1998," prosecutors have been able to directly try youth as adults for even minor offenses. Prior to Proposition 21, youth could have been transferred to the adult court through the judicial waiver process, known as a fitness hearing. ${ }^{126}$ More than half (53\%) of all youth tried as adults in California in 2007 were Latino. ${ }^{127}$

Judicial Waiver: In contrast to the national judicial waiver data, which found that Latino youth were 43\% more likely than white youth to be waived to the adult system, in California, Latino youth were 29\% more likely than white youth to be waived to the adult system using the CA judicial waiver process known as fitness hearing. ${ }^{128}$ However, another way of looking at the data is that white youth in California are nearly twice as likely (1.9 times) as Latino youth to be declared "fit" or "amenable to treatment" in the juvenile justice system and therefore do not get waived. 129 Although Latino youth in California are only $46 \%$ of the population, and $51 \%$ of the youth arrested, they comprised $64.3 \%$ of the youth receiving fitness hearings in 2007. Out of the 328 judicial waiver hearings, roughly one-third involved robbery cases, roughly $20 \%$ 
involved homicide cases, but another 20\% were misdemeanor cases. The majority (77\%) of the misdemeanor offense cases involved Latino youth. ${ }^{130}$

Adult Court Dispositions: This information reflects cases that were directly filed by prosecutors in addition to cases that may have received a judicial waiver hearing. Nearly 400 Latino youth received final adult court dispositions or sentences in 2007. Latino youth had the highest conviction rates of any racial or ethnic group. White, African-American, and "other" youth (the category that includes Native American and Asian Pacific Islanders) all had strikingly similar rates of dismissal $(21 \%, 21 \%$, and $24 \%$ respectively) and of conviction $(75 \%, 76 \%$, and $73 \%$ respectively), while Latino youth had a dismissal rate of $14 \%$ and a conviction rate of $83 \%$. The majority of the Latino youth (52\%) were sentenced to prison and/or the youth authority; $40 \%$ were given probation and or jail. ${ }^{131}$ In addition, Latino youth were more than twice as likely as white youth to be sentenced to the prison or youth authority. 132

\section{ARIZONA}

Prior to 1996, juvenile offenders in Arizona could be transferred to adult court for prosecution only upon the discretion of the juvenile judge. Arizona's transfer pathways changed as the result of a ballot initiative in that year (Proposition 102). The proposition created three new categories of automatic juvenile transfer through exclusion, based on the severity of the crime 
and past offenses. Only one year later, the legislature further expanded the prosecutor's discretion to transfer additional cases to the adult courts. ${ }^{133}$

The disproportionate contact of Latino youth with the Arizona justice system increases as youth penetrate the system. Latinos made up 39\% of juveniles ages 10 to 17 in the state of Arizona in 2007. ${ }^{134}$ Latinos are $40 \%$ of youth referred, $46 \%$ of youth detained, $48 \%$ of youth committed to the Arizona Department of Juvenile Corrections, and $61 \%$ of youth prosecuted as adults. ${ }^{135}$ Almost thirty percent of the youth who were transferred or direct filed in adult court had either no prior referrals to juvenile court, or had only one previous referral. 136

\section{LATINO YOUTH INCARCERATED IN ADULT FACILITIES}

While the public may think of jails and prisons interchangeably, the two facilities are quite different. Both are dangerous for children.

- "Jail" is a locked facility usually reserved for adults who are awaiting trial but in many states, people are sentenced to serve time in an adult jail for misdemeanor offenses and for one year or less.

- "Prison" is a locked facility usually reserved for adults who have been convicted of felony offenses and serving sentences of a year or longer. 
Will, a youth who was born in the U.S. and whose family emigrated from El Salvador in the early 1980s, was tried as an adult at the age of 16 . He served one year in an adult jail and nearly a year in federal prison. In an interview with Campaign for Youth Justice staff, he talked about his experiences as a youth in adult jail:

"[As a youth in an adult facility,] you're not really protected. They don't look after youth as they're supposed to. The [corrections officers] don't pay attention to anyone, and it's very violent in there. They do have programs, but they're regarded as privileges. Being young and incarcerated plays mind games with you, and some couldn't take it. I've seen suicides, and personally had to take down one of my friends who was trying to hang himself on the bars."

The U.S. Bureau of Justice Statistics estimates that 4,300 Latino youth are incarcerated in adult jails and prisons on any given day: 3,900 Latino males and 400 Latina females. ${ }^{137}$ The annual number of youth who are held in adult facilities is much higher to account for the high "turnover rate" of youth entering and exiting adult jails. 138 Despite the life-altering consequences of incarceration in adult facilities, relatively little attention has been given to these youth.

It is extremely difficult to keep youth safe in adult facilities. Youth placed with adults in jails are at great risk of physical and sexual assault. For example, according to a BJS study in 2005 and 2006, 21\% and $13 \%$, respectively, of the victims of inmate-on-inmate sexual violence in jails were youth under the age of $18^{139}$ - a surprisingly high percentage of victims 
considering that only $1 \%$ of all jail inmates are juveniles. ${ }^{140}$ Almost every jail and prison across America experiences problems with sexual violence. Even for youth not directly assaulted, the psychological effects of being in constant and legitimate fear of sexual assault, or of witnessing the sexual assault of others, can be devastating. Dr. Barry Krisberg, President of the National Council on Crime and Delinquency testified before the National Prison Rape Elimination Commission that many youth become disciplinary problems as a self-protective mechanism:

"What youth tended to do to protect themselves, particularly when the lights were out in the dormitory, was often to assault staff to get locked up, and they didn't mind being locked up 23 hours a day if that meant, as they would often say, not having to watch your back. So, you'd see staff, and, in fact, correctional officers and superintendents would routinely tell me that the lockup units were populated with essentially what they called protective custody cases. These were not gang-bangers, these were not violent youths, these were youth trying to escape the victimization that was going on in the dormitories. Another way out was to engage in abnormal behavior, like suicidal gestures, smearing feces on yourself or your bed, claiming that you were hearing voices, so that the psychologist and psychiatrist would, again, get you out of these terrible dormitories and into some single room where you'd feel some modicum of safety." 141 
Recognizing the risks to youth, some jail and prison staff separate youth from adult inmates. However, this is not an adequate solution either. Separating youth from adults can reduce the physical or emotional harm that may result from contact with adult offenders, but unfortunately these youth are then often placed in isolation, a dangerous setting for young people. Youth in isolation are frequently locked down 23 hours a day in small cells with no natural light. Even limited exposure to such an environment can cause anxiety and paranoia, exacerbate existing mental disorders, and increase risk of suicide. ${ }^{142}$

According to a study by the Bureau of Justice Statistics, youth in adult jails and prisons had the highest suicide rate of all inmates. Jail inmates under the age of 18 had a rate of 101 per 100,000 during 2000-2002. State prison inmates under the age of 18 had a rate of 52 per 100,000 during 2001-2002. ${ }^{143}$ By comparison, the suicide rate for 14- to 17-year-olds not in jail or prison during that same time period was just 5.33 per 100,000. ${ }^{144}$ This increased risk of suicide is particularly problematic for Latino youth who are already at higher risk for suicide. Latino youth in the general population are nearly twice as likely as white youth to attempt suicide ( $10.2 \%$ to $5.6 \%$ ). ${ }^{145}$

Another danger caused by housing youth within adult facilities is that jails expose youth to "role models." Researchers have found that young inmates try to find ways to fit into the inmate culture, which often involves adopting an identity that hides their youthful status and forces them to accept violence as a routine part of institutional life. ${ }^{146}$ Recognizing that adult 
facilities are not appropriate places for children, many of the major professional correctional organizations in the United States have issued policy positions either expressly disapproving of the housing of youth in adult correctional facilities or recognizing the need for their special protection including: the American Correctional Association (ACA); the National Commission on Correctional Health Care (NCCHC); the American Jail Association (AJA); the National Juvenile Detention Association (NJDA); the Council of Juvenile Correctional Administrators (CJCA); the American Probation and Parole Association (APPA); and the American Bar Association (ABA).

\section{Federal and State Laws Fail to Protect Youth}

The federal Juvenile Justice \& Delinquency Prevention Act (JJDPA) enacted more than three decades ago was designed to keep youth out of jails. However, there is a loophole - the law does not protect youth prosecuted in the adult criminal system even though the original intent of the federal law was to remove youth from adult jails altogether. Congress could fix this problem by amending the JJDPA to protect all youth from being placed in an adult jail. Similarly, states and counties should update their state statutes and policies to prohibit the placement of youth in adult jails and prisons.

States across the country have struggled to determine the best place to house youth prosecuted in the adult criminal system. While most states permit the pre-trial detention of youth being tried as adults in adult facili- 
ties, 10 states actually require that youth in the adult system be housed in jails. ${ }^{147}$ Although states have different laws regarding the pre-trial detention of youth in adult jails, jurisdictions across the country are making the choice to keep youth in juvenile facilities. No comparable research exists about whether state laws require youth convicted in the adult system to be housed in adult prisons.

- Nine out of ten (90\%) Latino youth ages 10 to 17 live in states that permit pre-trial detention in adult jails for youth prosecuted in the adult system. ${ }^{149}$

- One in ten Latino (10\%) youth ages 10 to 17 live in a state that mandates pre-trial detention in adult jails for youth tried in the adult criminal justice system. 150

According to a study of 40 large urban jurisdictions, Latino youth prosecuted in the adult system are routinely incarcerated in adult jails. Overall, a higher proportion of white youth are released pre-trial $(60 \%)$ than any other racial or ethnic categories. Most (54\%) Latino youth prosecuted in the adult system are detained pre-trial, and of those, $72 \%$ are held in adult jails. ${ }^{151}$

The most punitive response to juvenile crime is processing in the adult system and incarceration in adult prison. According to a report by the National Council on Crime and Delinquency, Created Equal: Racial and Ethnic Disparities in the U.S. Criminal Justice System, 
among the states reporting data in 2003, Latino youth were admitted to adult prison at 1.4 times the rate for white youth. States with the highest levels of disparity of Latino youth in adult prison (rates more than five times that for white youth) were California, Minnesota, North Dakota, Pennsylvania, and Wisconsin (see Table 5). ${ }^{152}$ A ratio that is greater than 1 indicates that Latino youth are more likely than white youth to be incarcerated in adult prison in that state; a ratio less than 1 indicates that Latino youth are less likely than white youth to be incarcerated in adult prison in that state.

\section{CULTURALLY COMPETENT APPROACHES TO SERVICES}

While there is research that evidence-based programs can improve interventions for most youth, there is limited evidence of successful outcomes for Latino youth. Most, if not all, of the evidence-based programs have been developed for and validated on white or AfricanAmerican youth, but often these programs have not been effective when adapted for Latino communities. ${ }^{154}$ There is a critical need to improve the services with proven ability to meet the needs of Latino youth and families. 
TABLE 5: RATIOS (COMPARED TO WHITE) OF NEW ADMISSIONS OF YOUTH TO ADULT PRISON IN CERTAIN STATES, 2003153

\begin{tabular}{|l|c|c|c|}
\hline & White & $\begin{array}{c}\text { African- } \\
\text { American }\end{array}$ & Latino \\
\hline Total Number & 972 & 2,046 & 469 \\
\hline Total RRI & 1.0 & 7.2 & 1.4 \\
\hline Alabama & 1.0 & 3.9 & 0.0 \\
\hline Alaska & 1.0 & 1.7 & 0.7 \\
\hline California & 1.0 & 28.4 & 5.6 \\
\hline Colorado & 1.0 & 12.8 & 4.8 \\
\hline Florida & 1.0 & 7.4 & 0.8 \\
\hline Georgia & 1.0 & 6.9 & 2.0 \\
\hline Illinois & 1.0 & 7.0 & 1.4 \\
\hline Iowa & 1.0 & 22.5 & 0.0 \\
\hline Louisiana & 1.0 & 6.1 & 0.0 \\
\hline Maryland & 1.0 & 15.8 & 0.0 \\
\hline Michigan & 1.0 & 5.0 & 0.6 \\
\hline Minnesota & 1.0 & 12.1 & 7.4 \\
\hline Mississippi & 1.0 & 4.9 & 0.0 \\
\hline Missouri & 1.0 & 1.9 & 2.0 \\
\hline Nebraska & 1.0 & 3.4 & 1.1 \\
\hline Nevada & 1.0 & 9.5 & 1.4 \\
\hline New & & & \\
\hline Hampshire & 1.0 & 0.0 & 0.0 \\
\hline New Jersey & 1.0 & 12.9 & 2.5 \\
\hline New York & 1.0 & 11.1 & 4.2 \\
\hline North Carolina & 1.0 & 4.5 & 1.2 \\
\hline North Dakota & 1.0 & 0.0 & 18.9 \\
\hline Oklahoma & 1.0 & 6.9 & 1.8 \\
\hline Oregon & 1.0 & 4.9 & 0.1 \\
\hline Pennsylvania & 1.0 & 19.9 & 8.1 \\
\hline South Carolina & 1.0 & 4.6 & 0.0 \\
\hline Tennessee & 1.0 & 9.5 & 2.4 \\
\hline Texas & 1.0 & 7.2 & 2.1 \\
\hline Utah & 1.0 & 0.0 & 0.0 \\
\hline Virginia & 1.0 & 6.1 & 1.0 \\
\hline Washington & 1.0 & 3.2 & 1.8 \\
\hline Wisconsin & 1.0 & 21.2 & 7.4 \\
\hline & & & \\
\hline
\end{tabular}


Speaking at a National Council of La Raza (NCLR) panel on ways to improve cultural and linguistic competence in the juvenile justice system, Wendy Jones of the National Center for Cultural Competence said, "The real key is that sometimes what seems logical or sensible if seen from our own cultural lenses might seem totally off the wall to someone else. It's always important to look at what you're seeing through a cultural lens that is trying to understand the full context of the situation. Being aware of the culture and its impact is critical to the review and selection of evidence-based and promising practices for adaptation to meet the unique preferences and needs of all families."155 When we speak about applying evidencebased practices to meet the needs of specific communities, we are really talking about modifying practices to meet the specific cultural, language, and contextual realities of clients. 156

Cultural competence should be defined as a system's, agency's, or organization's ability to have attitudes, behaviors, policies, practices, procedures, and fiscal and personnel resources that enable them to work effectively in cross-cultural situations. It involves more than just translating documents and providing services in a person's native language. Culturally competent services take into account cross-cultural factors and institutionalize such knowledge, adapting services to the communities they serve. Cultural competence has five basic elements: valuing diversity; self-assessment (the ability as an individual or agency to examine yourself and/or your organization); the ability to manage the dynamics of difference (being prepared with 
the awareness, knowledge, and skills to assist in smoothing out, negotiating, or navigating those differences); institutionalizing cultural knowledge (making sure that not just one person in your organization or on your staff has the knowledge or the skill to work with a particular cultural group or community, but ensuring that the organization is aware of this knowledge or skill and is making it a part of the organization's knowledge and skill set); and making adaptations to policies, service delivery, structures, attitudes, and behaviors. 157

The following are some problems that may occur from a lack of cultural competence, as related by a probation officer from Santa Cruz, California:

- The assumption that clients who are nodding and remaining silent understand what they are being told. They may just be trying to be polite, although they do not understand English.

- The refusal to release a boy to the care of his uncle because he is not a parent, while many immigrant youth live with extended families.

- The design of program schedules and curricula that do not reflect the clients being served, such as holding classes when most clients are working. 
Researchers have identified a continuum of cultural competence, from cultural destructiveness to cultural proficiency. Elements and strategies for cultural competence may include:

- Providing training to juvenile justice personnel in how cultural beliefs influence their approach to serving their clients, and

- Providing culturally appropriate services that incorporate cultural values and traditions. ${ }^{158}$

Culturally competent staffing practices include the hiring, promotion, and retention at all levels of qualified, competent personnel who belong to the racial and ethnic groups that the agency serves. These may also include creating an assessment tool to decide whether an organization's staff truly reflects the community it serves. 159

\section{NATIONWIDE INITIATIVES TO REDUCE RACIAL AND ETHNIC DISPARITIES}

Since the Disproportionate Minority Contact (DMC) provision was first added to the Juvenile Justice and Delinquency Prevention Act (JJDPA) in 1988, there has been progress in those jurisdictions that have made a commitment to reducing racial and ethnic disparities. Today, there are several nationwide efforts aimed at reducing disparities.

For the past 15 years, the Juvenile Detention Alternatives Initiative (JDAI), a project of the Annie E. 
Casey Foundation, has demonstrated that jurisdictions can safely reduce reliance on secure detention and generally strengthen their juvenile justice systems through a series of inter-related reform strategies. From the beginning, JDAI recognized that juvenile detention reform efforts must reflect the reality that youth of color bear the brunt of policies that lead to arrest, referral, detention, adjudication, and imprisonment of young people. ${ }^{160} \mathrm{JDAI}$ is now being replicated in more than 100 jurisdictions across the country.

A key partner in the JDAI initiative is the W. Haywood Burns Institute, an organization that has been working to reduce the overrepresentation of youth of color in juvenile justice systems since 2001.161 The Burns Institute works with local jurisdictions across the country to reduce racial disparities in their juvenile justice systems by improving decision-making, court processes, and alternatives to incarceration. The Burns Institute provides technical assistance to jurisdictions prepared to implement institutional changes to remedy disparities. It engages traditional and non-traditional stakeholders in an intensive data-driven examination of their policies and practices, followed by a remedial plan aimed at measurable results. A key component of reducing racial disparities is the use of effective, culturally appropriate, neighborhood-based programming that primarily serves communities of color.

The John D. and Catherine T. MacArthur Foundation began making grants in the field of juvenile justice in 1996. Since then, the foundation has launched Models for Change, an effort to create 
successful and replicable models of juvenile justice system reform through targeted investments in key states. ${ }^{162}$ The National Council of La Raza's (NCLR) Latino Juvenile Justice Network (LJJN) is designed to engage local Latino leaders in systems reform efforts as part of the Models for Change initiative. LJJN works with the Center for Children's Law and Policy (CCLP), as well as other national and state-based organizations and government agencies, to develop and implement systems reform that will reduce racial and ethnic disparities. The CCLP coordinates the DMC reduction activities in each of the four Models for Change states (Illinois, Louisiana, Pennsylvania, and Washington) and manages the DMC Action Network, a network of 12 sites across the country working to achieve sustainable reductions in racial and ethnic disparities in the juvenile justice system. ${ }^{163}$

Successful approaches to addressing DMC are targeted and tailored to the specific state, county, city, or region; however, these approaches share some consistent commonalities:

- Strengthened leadership through creation of DMC committees and focused state efforts to reduce racial and ethnic disparities.

- Collection and monitoring of state and local data to improve states' ability to assess and address the root causes of DMC. 
- Standardized and objective screening instruments used by decision-makers, such as judges, to eliminate the impact of subtle stereotypes and biases.

- Community-based prevention, intervention, and diversion efforts to prevent involvement of youth in the juvenile justice system, encourage diversion, and serve court-involved youth close to home.

- Community empowerment by engaging communities at the local level to assist with DMC reduction activities.

- Efforts to increase cultural sensitivity to make system stakeholders more sensitive to the needs of youth.

- Legislative changes to reduce the disparate impact of state laws. ${ }^{164}$

\section{Alternatives to Detention in Santa Cruz, California}

Santa Cruz County is located in northern California and is home to the fertile Pajaro Valley, where many Latino seasonal migrant workers are employed in the agriculture sector. In the mid 1990s, Latinos made up about $70 \%$ of the population in the juvenile halls although they were only $30 \%$ of the court-age (10 to 17) population. ${ }^{165}$ To reduce DMC in the county, Santa Cruz became a pilot site for the Juvenile Detention Alternatives Initiative and set up a task 
force to evaluate the problem. As a result of the implemented interventions, Santa Cruz has significantly narrowed the gap between Latino youth representation in the general population and the detention population. 166

The DMC taskforce, composed of Latino community leaders and justice system representatives, identified the decision points where overrepresentation was most pronounced and developed an array of strategies to reduce DMC. For example, upon discovering that Latino youth generally did not participate in diversion programs, the county created additional programming targeting the needs of Latino youth. ${ }^{167}$ The county also developed an objective screening process to detain only high-risk offenders and developed alternative programs and procedures for low- and medium-risk youth. Santa Cruz built meaningful partnerships with community-based organizations to provide culturally responsive alternatives to detention. 168 Efforts were made to adapt probation department hours, staffing practices, and communication strategies to better serve Latinos. ${ }^{169}$

As a result of these measures, the proportion of Latinos in detention fell to under $50 \%$ by 2001 . From 1998 to 2007, the average daily population of Latino youth in detention fell from 34 to $17 .{ }^{170}$ In addition, juvenile felony arrests went down by $48 \%$ and misdemeanor arrests were down by $43 \%$. Sharply reducing its detention population, Santa Cruz's detention reform efforts resulted in saving the county millions of dollars (by eliminating the need to construct a new detention center) while concurrently experiencing a reduction in juvenile crime. ${ }^{171}$ 
Berks County, Pennsylvania, which includes the City of Reading, is a community in the midst of change. The proportion of Latino residents has more than doubled since 1990, from less than 6\% to almost 13\%. Latinos are now $20 \%$ of youth under 18 in the county. In late 2005, Berks County became part of the Models for Change initiative. Along with three other counties in Pennsylvania, Berks County is focusing on reducing racial and ethnic disparities and guaranteeing fair and unbiased treatment in the juvenile justice system. Guided by a diverse group of court and community stakeholders, the Berks County Project to Reduce Racial and Ethnic Disparities in Juvenile Justice first gathered and analyzed quantitative and qualitative data. The county chose to focus its efforts on: language capability and cultural diversity; detention screenings and alternatives to incarceration; recruitment of nontraditional service providers; and education and workforce development. ${ }^{172}$

In addition to early accomplishments translating court forms, training stakeholders in cultural competence and education rights of youth, and improving availability of court interpreters, the county is now seeing measurable reduction in its detention and placement populations. Since 2007 , the county has reduced its detention population by $45 \%$ without compromising public safety. This means that on any given day in the first quarter of 2009, there are 8 fewer Latino youth in detention than in the first quarter of 2007. Forty-five fewer youth of color were removed 
from their homes post-adjudication in 2008 than in 2007 , and the county is on course for a much bigger drop in 2009.

The county's successful drop in detention is fueling further reforms at its Youth Center. Because stakeholders have realized that the county does not need all the beds at the detention center, it has permanently removed 24 beds from its secure detention program, altering the space to expand a non-secure treatment program that provides job readiness and other programming to youth. ${ }^{173}$

\section{EFFECTIVE COMMUNITY-BASED PROGRAMS}

Across the country, community-based organizations are making a difference in the lives of Latino youth. From the Latin American Youth Center in Washington DC to GRASP (Gang Rescue and Support Project) in Denver, Colorado, to Palenque in the Washington Heights/Inwood community in New York City, community-based organizations across the country are having an enormous positive impact on the lives of Latino youth. Below are profiles of programs known to work with court-involved Latino youth. Many of these organizations developed programs that responded to the self-identified needs of the community and explicit efforts were made to strengthen the community's own ability to develop and support programs that work with youth. ${ }^{174}$ 
Daniel "Nane" Alejandrez, founder of Barrios Unidos, has said "We need to stop the flow of men into [prisons]. The prison-industrial complex is a multimillion dollar operation. It costs so much money to incarcerate a person that we could send him to any university in the country for the amount of money it takes to keep him behind bars. We also have to ask ourselves, why do we have so many people of color in the prisons? Does the community really feel safe by putting all these people into prison? What we do know is that it's broken up many families. And we know that if men are getting out of institutions with nowhere to go, no jobs, and no skills, they're going to go right back to where they were. When they come out, we want to make sure that they have some support so that they don't start committing crimes and so that they can support their families." 175

Drawing heavily on the Chicano/Mexicano culture, a primary focus of the Barrios Unidos peace movement has been to build community-based structures to support organizing and social cohesion by restoring the cultural traditions that have historically bound families and communities together. Barrios Unidos operates on the premise that the root causes of interpersonal and street violence are found in the social conditions of poverty including racism, discrimination, inadequate housing and education, unemployment, poor healthcare, and other indices of inequity. In this regard, the Barrios Unidos movement emerged from and continues to uphold the ongoing struggle for civil

\section{4}


rights in the United States. Barrios Unidos has assimilated into its work the connection between cultural consciousness and political action, a commitment to working in interracial alliances and coalitions, the promotion of community self-reliance and economic development, and non-violent action for social change. Barrios Unidos is not a traditional youth service organization, but is instead a hybrid social enterprise that works in a holistic fashion with youth, families, the public, and the private sector to build human and community capital thereby strengthening communities and, as a result, the whole of society. ${ }^{176}$

\section{Southwest Key Programs}

Dr. Juan Sanchez founded Southwest Key Programs in 1987 as the Texas Key Program. With a fundamental belief that young people are best served in their communities with culturally competent services, Southwest Key has grown to become one of the country's largest care providers for unaccompanied immigrant children and juvenile justice system-involved youth. With 55 programs in seven states across the nation, Southwest Key positively impacts the lives of thousands of youth each day.

Southwest Key Programs' core focus has been serving young people at risk or in trouble. They provide sentencing options for juvenile courts across the country, which allows them to divert young people from further involvement in the system. Programs are based in the community, supervising youth and providing them with a variety of services to prevent them from 
committing delinquent acts in the future. This allows youth to stay at home rather than being removed and incarcerated, while upholding public safety. As Southwest Key Programs has grown, it has expanded its reach to wrap services around entire families: they visit daily the youth who are referred in their homes and provide the household with individual and group counseling and crisis intervention, as well as coordinate with a number of providers to help the family meet its needs. In the last few years, the continuum has been completed by developing the capacity of entire communities through quality education, child care brokerage, and job creation with the goal of preventing young people from getting involved in the juvenile justice system. ${ }^{177}$

Chicanos Por la Causa, Inc.

Chicanos Por La Causa, Inc. (CPLC) is a statewide community development corporation in Tucson, Arizona, committed to building stronger, healthier communities by being a leading advocate, coalition builder, and direct service provider. The CPLC Youth Center, the Corazon de Aztlan Youth Leadership Retreat, the Nahui Ollin Wellness program, and the Aguila Support Group integrate a vibrant and historically correct cultural foundation and focus in their programming.

The Nahui Ollin curriculum, utilized across all programming, stresses the need for optimal health of mind, body, spirit, and community through the incorporation of activities that explore ancestral and 
modern history, self-empowerment, family dynamics, communication, and leadership development. CPLC programming encourages civic engagement, advocacy, and strengthening of mind, body, spirit, and community. Activities include youth development opportunities through leadership conferences, retreats, cultural development training, public health education, skill building, scholarship assistance, and mentoring.

CPLC's bilingual and bicultural staff have recently implemented a community-based support group for pre-adjudicated youth, mainly Latino. The Aguila Support Group is gender-responsive and culturally competent. The name, Aguila, is Spanish for eagle. The eagle represents the vision and the physical and spiritual renovation, purification, and cleansing of our selves and our environment; the presence of freedom, liberty and the "free warrior." The program model is based on the premise that male youth, mainly Latino, have the strength and capacity to make good decisions, have positive interactions, and experience healthy relationships. The mission of the Aguila Support Group is to provide a pathway for all youth to reconnect and awaken their inner strength and will to make decisions that transform their lives. ${ }^{178}$

Homegirl Café (Homeboy Industries)

Guided by the motto "Nothing stops a bullet like a job," Homeboy Industries provides at-risk youth with a range of employment services, including job placement, counseling, community service opportunities and tattoo removal. Homeboy Industries grew out of "Jobs for a Future," a program created in 1988 by 
Father Gregory Boyle, offering alternatives to gang violence in some of the toughest neighborhoods in Los Angeles. ${ }^{179}$

Homegirl Café, a café employing about 25 young women who are in training to learn the various aspects of restaurant and catering work, was opened in April 2005 to offer opportunities to women who are ex-gang members or are affected by the gang climate. Gang violence destroys families, neighborhoods, and communities. It deprives the Latino community from having peaceful and productive lives; instead, parents constantly worry about their children and youth fear for their lives. The focus should be on education and building a brighter future. According to Homeboy Development Director Kaile Shilling, "The gang violence has had a real impact on the women. Even if they themselves are not with a gang, they are the sisters, mothers, girlfriends, friends of gang members so they feel the effects of the violence and the gang lifestyle. Homegirl Café gives them an alternative, a chance to make a positive change in their lives." 180

In addition to providing job training and placement assistance and other free programs, a distinctive feature of Homeboy Industries continues to be its small businesses, where the most difficult-to-place individuals are hired in transitional jobs, thus giving them a safe, supportive environment in which to learn both concrete and soft job skills, while simultaneously building their resume and work experience. Former rivals find themselves working side by side, finding true community and friendship in place of the limited community of gang life. Homeboy's businesses now 
include the Homeboy Bakery, Homeboy Silkscreen, Homeboy Maintenance, Homeboy Merchandise, Homegirl Café, and Homeboy Press. ${ }^{181}$

\section{POLICY RECOMMENDATIONS}

To minimize the negative impact of transfer laws on Latino youth as documented in this policy brief and improve services for Latino youth and families, federal and state policymakers should take immediate action.

Congress And the New Administration SHould:

- Ensure equitable investment in the development of evidence-based programs designed to meet the needs of Latino youth and families. Use knowledge from community leaders and existing community programs, such as the programs profiled in this brief, to build the research base.

- Strengthen the "Disproportionate Minority Contact (DMC)" core requirement of the Juvenile Justice and Delinquency Prevention Act (JJDPA) by giving states specific guidance on action steps to reduce both racial and ethnic disparities by employing proven methodologies such as identifying and analyzing key decision points, collecting data at each point to determine where disparities exist, developing a work plan, and publicly reporting on progress.

- Close the loophole in the JJDPA allowing youth charged as adults to be housed in adult jails. The "Jail Removal" and "Sight and Sound" core 
requirements of the JJDPA should be expanded to apply to youth who are charged in the adult system. In addition, encourage states to house youth convicted in adult court in juvenile facilities rather than adult prisons by resolving the "Adult Inmate" issue.

- Improve data systems to track youth prosecuted in the adult criminal system and ensure data is disaggregated by race and ethnicity.

- Fully fund existing programs like the JJDPA and the Juvenile Accountability Block Grants Program (JABG), and also fund comprehensive prevention programs, such as the Youth PROMISE Act, that would prevent crime before it occurs and would provide intervention programs to redirect youth toward law-abiding and productive futures.

- Ensure due process protection and access to quality legal assistance for children arrested and detained in the course of immigration enforcement actions in accordance with American Bar Association policy.

- Improve re-entry services for youth and repeal provisions of federal laws that make it more difficult for youth convicted in the adult system to reintegrate into the community successfully (e.g., limitations on the eligibility of financial aid for college, food stamps, or Medicaid).

- Oppose legislation that increases the transfer of youth to the adult criminal system, mandatory 
minimum sentences (e.g., gang enhancements), or criminal penalties for civil violations of immigration laws.

State ANd Local Policymakers SHOULD:

- Immediately stop housing young people in adult jails and prisons.

- Redirect resources from incarceration to culturally competent in-home and community-based services for at-risk youth and youth already in the juvenile or adult justice systems, such as the programs profiled in this brief.

- Make a commitment to reducing racial and ethnic disparities by partnering with community leaders, parents, and youth to identify community needs; collect and disseminate accurate data disaggregated by race and ethnicity at the key decision point (including waiver to adult court); develop a work plan; and publicly report on progress.

- Increase the age of juvenile court jurisdiction to 18 .

- Remove statutory exclusion and prosecutorial discretion laws, and use judicial waiver as the sole mechanism for trying a young person as an adult.

- Ensure that youth are treated fairly in court. Youth should receive quality and effective legal counsel, with translators for limited-English-proficient youth and their families when appropriate. 
For Latino youth with jury trials, make sure the Latino community is not unfairly excluded from the jury pool.

- Provide due process protection and access to quality legal assistance for children arrested and detained in the course of immigration enforcment actions, in accordance with American Bar Association policy.

- Enact laws, such as a juvenile clemency board or a "Second Look" statute, that recognize a youth's ability to mature and be rehabilitated by permitting an individualized reassessment of youth serving long sentences in the adult system.

- Improve data systems to track youth prosecuted in the adult criminal system and disaggregate data by race and ethnicity. If the state has specific gang-related penalties, data systems should also track gang-related offense prosecutions and convictions.

- Repeal state laws regarding employment, voting, and other restrictions for people with criminal histories that make it more difficult for youth convicted in the adult system to reintegrate into the community successfully.

- Reconsider law enforcement tactics and the impact of policies related to racial and ethnic profiling, enforcement of gang statutes (e.g., gang injunctions, gang databases), and immigration enforcement and their impact on the Latino community as a whole. 
1 Author's calculations from West, H.C. \& Sabol, W.J. (2009, MARCH). PRISON INMATES AT MIDYEAR 2008 - STATISTICAL tables. Washington, DC: U.S. Department of Justice, Bureau of Justice Statistics; and Sickmund, M, Sladky, T.J., AND KANG, W. (2008). CENSUS OF JUVENILES IN RESIDENTIAL PLACEMENT DATABOOK. AVAILABLE FROM HTTP://WWW.OJIDP.NCJRS.GOV/OISTATBB/CIRP. THIS ESTIMATE INCLUDES THE MAJORITY (67\%) OF DETAINEES HELD BY THE U.S. IMMIGRATION AND CUSTOMS ENFORCEMENT (ICE).

2 Villaruel, F.A., Walker, N.E., Minifiee, P., RiveraVázquez, O., Peterson, S., \& Perry, K.. (2002, July). ¿DÓNDE ESTÁ LA JUSTICIA? A CALL TO ACTION ON BEHALF OF LATINO AND LATINA YOUTH IN THE U.S. JUSTICE SYSTEM. WASHINGTON, DC: BUILDING BLOCKS FOR YOUTH.

3 Walker, N.E., Villaruel, F.A., Senger, J.M., \& Arboleda, A.A. (2004). LOST OPPORTUNITIES: THE REALITY OF LATINOS IN THE U.S. CRIMINAL JUSTICE SYSTEM. WASHINGTON, DC: THE National Council of La Raza.

4 Author's calculations from West, H.C. \& Sabol, W.J. (2009, MARCH). PRISON INMATES AT MIDYEAR 2008 - STATISTICAL tables. Washington, DC: U.S. Department of Justice, Bureau of Justice Statistics; and Sickmund, M, Sladky, T.J., AND KANG, W. (2008). CENSUS OF JUVENILES IN RESIDENTIAL PLACEMENT DATABOOK. AVAILABLE FROM HTTP://WWW.OJJDP.NCJRS.GOV/OJSTATBB/CJRP. THIS ESTIMATE INCLUDES THE MAJORITY (67\%) OF DETAINEES HELD BY THE U.S. IMMIGRATION AND CUSTOMS ENFORCEMENT (ICE).

5 Author's calculations from Sickmund, M., Adams, B., Puzzanchera, C., Livsey, S., \& Knoll, C. (2008, November 14). Latinos in the Juvenile Justice System. The Office of Juvenile Justice and Delinguency Prevention. Presentation to the American Society of Criminology, St. Louis, MO.; Hartney, C. \& Vuong, L. (2009, March). Created Equal: RaCial and Ethnic Disparities in the U.S. CRiminal Justice System. San Francisco, CA: National Council on Crime AND DELINQUENCY.

6 Hartney, C. \& Vuong, L. (2009, March). Created Equal: RACIAl and ETHNic Disparities IN THE U.S. CRIMINAl Justice System. San Francisco, CA: National Council on Crime AND DELINQUENCY.

7 Author's calculations from Puzzanchera, C., Sladky, A. AND KANG, W. (2008). EASY ACCESS TO JUVENILE POPULATIONS: 1990-2007. Pittsburgh, PA: National Center for Juvenile Justice. Available From HTTP://WWW.OJIDP.NCJRS.GOV/OJSTATBB/EZAPOP; GRIFFIN, P. (2008). NATIONAL OVERVIEWS. STATE JUVENILE JUSTICE 
Profiles. Pittsburgh, PA: National Center for Juvenile JustiCE. AVAILABLE: HTTP://WWW.NCII.ORG/STATEPROFILES; AND Arya, N. (2007, November). JAILING JUVENILES: THE DANGER OF INCARCERATING YOUTH IN ADULT JAILS IN AMERICA. Washington, DC: The Campaign For Youth Justice.

8 JusZKiEWICZ, J. (2007, OCTOBER). TO PUNISH A FEW: TOO MANY YOUTH CAUGHT IN THE NET OF ADULT PROSECUTION. Washington, D.C.: Campaign For Youth Justice.

9 Lopez, M.H. \& Livingston, G. (2009, APril). HisPANiCS IN THE CRIMINAL JUSTICE SYSTEM: LOW CONFIDENCE, HIGH exposure. Washington, DC: PeW Hispanic Center.

10 Hynton Hoytt, E., Schiraldi, V., Smith, B.V., \& ZiEDENBERG, J. (2001). REDUCING RACIAL DISPARITIES IN JUVENILE DETENTION. PATHWAYS TO JUVENILE DETENTION REFORM, Volume 8. The Annie E. Casey Foundation.

11 U.S. Census Bureau. (2008). InCOME, POVERTY, AND HEALTH INSURANCE COVERAGE IN THE UNITED STATES: 2007. WASHINGTON, DC: AUTHOR.

12 Morin, J.L. (2009). LATINO/A RIGHTS AND JUSTICE IN THE UNited States: PERSPECTIVES AND APPROACHES (2ND ED.). Durham, NC: Carolina ACADEMic Press.

13 IBID.

14 IBID.

15 IBID

16 Delgado, R. (2005). RODRIGO AND REVISIONISM: RELEARNING THE LESSONS OF HISTORY. NORTHWESTERN UNIVERSITY LAW REVIEW, 99(2), 805-837.

17 U.S. Census Bureau. (2009). Statistical abStract of the United States. Table 18. Washington, DC: Author.

18 Sickmund, M., Adams, B., Puzzanchera, C., Livsey, S., \& KNOll, C. (2008, November 14). LATINOS IN THE JUVENILE JUSTICE SYSTEM. THE OFFICE OF JUVENILE JUSTICE AND Delinguency Prevention. Presentation to the American Society of Criminology, St. Louis, MO.

19 U.S. Census Bureau. (2009). Statistical abstract of the United States. Table 9. Washington, DC: Author. 
20 Sickmund, M., Adams, B., Puzzanchera, C., Livsey, S., \& KNOLl, C. (2008, November 14). LATINOS IN THE JUVENILE JUSTICE SYSTEM. THE OFFICE OF JUVENILE JUSTICE AND

Delinguency Prevention. Presentation to the American Society of Criminology, St. Louis, MO.

21 Montero Sieburth, M., \& Villarruel, F. A. (Eds.). (2000). MAKING INVISIBLE LATINO ADOLESCENTS VISIBLE: A CRITICAL APPROACH FOR BUILDING UPON LATINO DIVERSITY. NEW YORK, NY: FALMER PRESS.

22 Verdugo, R. (2006). A REPORT ON THE StATUS OF LATINOS IN EDUCATION: OVERCOMING A HISTORY OF NEGLECT.

Washington, DC: The National Education Association.

23 Pew Hispanic Center. (2006). Table 5: Detailed latino ORIGIN, 2006. StaTISTICAL PORTRAIT OF LATINOS IN THE UNITED STATES.

24 IBID.

15 Verdugo, R. (2006). A REPORT ON THE StATUS OF LATINOS IN EDUCATION: OVERCOMING A HISTORY OF NEGLECT.

Washington, DC: The National Education Association.

26 Pew Hispanic Center. (2006). Table 5: Detailed latino ORIGin, 2006. Statistical Portrait of Latinos in the UNited STATES.

27 Verdugo, R. (2006). A REPORT ON THE STATUS OF LATINOS IN EDUCATION: OVERCOMING A HISTORY OF NEGLECT.

Washington, DC: The National Education Association.

28 Suarez-Orozco, C., \& Carhill, A. (2008). Afterword: NEW DIRECTIONS IN RESEARCH WITH IMMIGRANT FAMILIES AND THEIR CHILDREN. IN H. YOSHIKAWA \& N. WAY (EDS.). BEYOND THE FAMILY: CONTEXTS OF IMMIGRANT CHILDREN'S DEVELOPMENT. New Directions for Child AND AdOLESCENT DeVElopment, $121,87-104$.

29 Davy, M. (2006, April). The Central-American FOREIGN BORN IN THE United States. Migration InFormation SOURCE. Washington, DC: The Migration Policy Institute.

30 DOLAN, S.L. (2009). MisSing OUT: LATINO STUDENTS IN America's SCHOOLS. WASHington, DC: The National COUNCIL OF LA RAZA.

31 IBID. 
32 Passel, J. \& Cohn, D. (2009, APril). A PORTRAIT OF UNAUTHORIZED IMMIGRANTS IN THE UNITED STATES. WASHINGTON, DC: The PeW HisPanic CEnTER.

33 U.S. OfFICE OF IMMIGRATION StaTistics. (2008, SEPTEMBER). 2007 YEARBOOK OF IMMIGRATION STATISTICS. WASHINGTON, DC: AUTHOR.

34 Littlefield, L. (2005, August). UnACCOMPANiEd IMMIGRANT AND Refugee minors. ImMigrant Policy Project. Denver, CO: The National Conference of State LEGISLATURES.

35 Southwest Key Program. (N.D.). Southwest Key PROGRAM DESCRIPTIONS: UNACCOMPANIED MINOR PROGRAMS. Austin, TX: AUTHOR.

36 SAMPSON, R.J. (2008). RETHINKING CRIME AND IMMIGRATION. CONTEXTS, 7 (1) PP.28-33.

37 Butcher, K.F., \& Piehl, A.M. (2008, February). Crime, CORRECTIONS, AND CALIFORNIA: WHAT DOES IMMIGRATION HAVE to DO WITH IT? CALIFORNIA COUNTS, 9(3), 1-23.

38 THE PUBLIC SAFETY AND CIVIL RIGHTS IMPLICATIONS OF STATE AND LOCAL ENFORCEMENT OF FEDERAL IMMIGRATION LAWS:

TESTIMONY BEFORE SUBCOMMITTEE ON IMMIGRATION, Citizenship, REFUGEes, BORDER SECURITY, AND INTERNATIONAL LAW OF THE HOUSE JUdiCIARY COMMITTEE, $111 \mathrm{TH}$ CONG. (2009, APRil 2) (TESTIMONY OF THE AMERICAN CiVIL LiberTiES UNION).

39 IBID.

40 Immigration Legal Resource Center. (2008, June). IMMIGRATION OPTIONS FOR UNDOCUMENTED IMMIGRANT CHILDREN. SAN FranCISCO, CA: AUthor.

41 U.S. IMMigRATION AND CUSTOMS ENFORCEMENT. (N.D.). OPERATION COMMUNITY SHIELD: TARGETING VIOLENT TRANSNATIONAL STREET GANGS. WASHINGTON, DC: AUTHOR.

42 Franco, C. (2008, January). The MS-13 and 18th Street GANGS: EMERGING TRANSNATIONAL GANG THREATS? CRS REPORT FOR CONGRESS. WASHINGTON, DC: CONGRESSIONAL RESEARCH SERVICE.

43 Greene, J., \& Pranis, K. (2007, July). Gang Wars: The FAILURE OF ENFORCEMENT TACTICS AND THE NEED FOR EFFECTIVE PUBLIC SAFETY STRATEGIES. WASHINGTON, DC: THE JUSTICE POLICY INSTITUTE. 
44 SNYDER, H. \& SiCKMUND, M. (2006). JUVENILE OFFENDERS AND VICTIMS: 2006 NATIONAL REPORT. WASHINGTON, DC: U.S. Department of Justice, Office of Justice Programs, Office of JuVEnile Justice AND DELINQUENCy PREVEntion.

45 Scott, E.S. \& Steinberg, L. (2008). Adolescent DeVelopMENT AND THE REGULATION OF YOUTH CRIME. THE FUTURE OF CHILDREN, 18(2), 15-33.

46 Bruder, M. (2009, May). SAY CHEEse! Examining THE CONSTITUTIONALITY OF PHOTOSTOPS. AMERICAN UNIVERSITY LAW REVIEW, 58, 1693-1728; AND INSTITUTE FOR INTERGOVERNMENTAL RESEARCH. (2009). COMPILATION OF GANG-RELATED LEGISLATION. TALlahasseE, FL.

47 Lopez, E.M. ET AL. (2006, MaY). LATINO HIGH SCHOOL STUDENTS' PERCEPTIONS OF GANGS AND CREWS. JOURNAL OF AdOLESCENT RESEARCH, 21 (3), 299-318.

48 Bruder, M. (2009, MAY). SAY CHEESE! EXAMINING THE CONSTITUTIONALITY OF PHOTOSTOPS. AMERICAN UNIVERSITY LAW REVIEW, 58, 1693-1728.

49 Delgadillo, R. (2008, August 18). Going global to FIGHT GANGS [EDITORIAL]. THE LOS ANGELES TIMES.

50 SEElKe, C.R. (2008, OCTOBER). CRS REPORT FOR CONGRESS: Gangs in Central America. Washington, DC:

CONGRESSIONAL RESEARCH SERVICE.

51 The Advancement Project. Citywide gang activity REDUCTION STRATEGY: PHASE III REPORT. RETRIEVED FROM HTTP://WWW.ADVANCEPROI.ORG/DOC/P3 EXEC SUMM.PDE. WASHINGTON, DC: AUTHOR.

52 The Annie E. Casey Foundation. (2008). A roadmap for JUVENILE JUSTICE REFORM. 2008 KIDS COUNT ESSAY AND DATA BOOK. BALTIMORE, MD: AUTHOR.

53 Campaign for Youth Justice. (2007). THE CONSEquenCES AREN'T MINOR: THE IMPACT OF TRYING YOUTH AS ADULTS AND STRATEGIES FOR REFORM. WASHINGTON, DC: AUTHOR.

54 Scott, E.S. \& Steinberg, L. (2008). AdOlescent DeVelopMENT AND THE REGULATION OF YOUTH CRIME. THE FUTURE OF CHILDREN, 18(2), 15-33.

55 Roper V. Simmons, 543 U.S. 551 (2005). 
56 Centers for Disease Control and Prevention. (2007, NOVEMBER). EFFECTS ON VIOLENCE OF LAWS AND POLICIES FACILITATING THE TRANSFER OF YOUTH FROM THE JUVENILE TO THE ADULT JUSTICE SYSTEM: A REPORT ON RECOMMENDATIONS OF THE TASK FORCE ON COMMUNITY PREVENTIVE SERVICES. MMWR 2007;56(RR09);1-11. AtLanta, GA: Author.

57 Redding, R.E. (2008, August). JUVENILE TRANSFER LAWS: AN EFFECTIVE DETERRENT TO DELINQUENCY? WASHINGTON, DC: Office of Juvenile Justice and Delinquency Prevention.

58 Arya, N. (2007, November). JaILING JUVENILES: THE DANGER OF INCARCERATING YOUTH IN ADULT JAILS IN AMERICA. Washington, DC: The CAMPaign For Youth Justice.

59 Sickmund, M., Adams, B., Puzzanchera, C., Livsey, S., \& KnOlL, C. (2008, November 14). LATINOS IN THE JUVENILE JUSTICE SYSTEM. THE OFFICE OF JUVENILE JUSTICE AND

Delinguency Prevention. Presentation to the American SOCIETy OF CRiminology, St. Louis, MO.

60 Education WeEk. (2008). Diplomas count 2008: SCHOOL TO COLLEGE: CAN STATE P-16 COUNCILS EASE THE TRANSITION? BETHESDA, MD: AUTHOR.

61 U.S. Census Bureau. (2009). Statistical abstract of the United States. Table 221. Washington, DC: Author.

62 Sickmund, M., Adams, B., Puzzanchera, C., Livsey, S., \& Knoll, C. (2008, NOVEMBer 14). LATINOS IN THE JUVENILE JUSTICE SYSTEM. THE OFFICE OF JUVENILE JuSTICE AND

Delinguency Prevention. Presentation to the American Society of Criminology, St. Louis, MO.

63 Harlow, C.W. (2003, January). EDUCATION AND CORRECTIONAL POPULATIONS. WASHINGTON, D.C.: U.S. DEPARTMENT OF Justice, Office of Justice Programs, Bureau of Justice STATISTICS.

64 Levin, H., Belfield, C., Muenning, P., \& Rouse, C. (2007, JANUARY). THE COSTS AND BENEFITS OF AN EXCELLENT AN EDUCATION FOR ALL OF AMERICA'S CHILDREN. NEW YORK, NY:

Columbia Teachers College.

65 Eggleston, A. (N.D.). Perpetual punishment: The ConseQUENCES OF ADULT CONVICTIONS FOR YOUTH. WASHINGTON: DC: CAMPAign For Youth Justice.

66 IBID.

67 IBID. 
68 The Rockefeller Foundation. (2008, June). NATional AMERICAN WORKER SURVEY: 2008 NATIONAL SURVEY RESULTS. NEW YORK, NY: AUTHOR.

69 Annie E. Casey Foundation. (2008). Kids Count data CENTER. BALTIMORE, MD: AutHOR. ReTRIEVED FROM: HTTP://WWW.KIDSCOUNT.ORG/DATACENTER.

70 Federal Bureau of Investigation. (2008, September). Crime in the United States, 2007. Washington, DC: AUTHOR.

71 Sickmund, M., Adams, B., Puzzanchera, C., Livsey, S., \& KNOLl, C. (2008, NOVEMBER 14). LATINOS IN THE JUVENILE JUSTICE SYSTEM. THE OfFICE OF JuVENILE JUSTICE AND Delinguency Prevention. Presentation to the American Society of Criminology, St. Louis, MO.

72 IBID.

73 IBID.

74 IBID.

75 IBID.

76 IBID.

77 IBID.

78 Puzzanchera, C., Sladky, A. and Kang, W. (2008). Easy ACCESS to JUVENILE POPUlations: 1990-2007. PitTSBuRgh, PA: National Center for Juvenile Justice. Online. Available FROM HTTP://WWW.OJJDP.NCIRS.GOV/OISTATBB/EZAPOP; ARIZONA Department of Public Safety. (n.D.). Crime in Arizona 2007. Phoeniz, AZ: Author.; California Department of Justice. (N.D.). JUVENILE JUSTICE IN CALIFORNIA 2007. Sacramento, CA: Criminal Justice Statistics Center; and California Department of Justice. (N.D.). Adult and JUVENILE ARRESTS REPORTED, 2007. SACRAMENTO, CA: CRIMINAL Justice Statistics Center.

79 IBID.

80 Arizona Department of Public Safety. (N.D.). Crime in Arizona 2007. Phoeniz, AZ: Author.; And California DEPARTMENT OF JUSTICE. (N.D.). JUVENILE JUSTICE IN California 2007. SaCramento, CA: CRiminal Justice STATISTICS CENTER 
81 California Department of Justice. (N.D.). JuVEnile Justice in CAlifornia 2007. SACramento, CA: Criminal Justice STATISTICS CENTER.

82 Arizona Department of Public Safety. (n.D.). Crime in Arizona 2007. Phoenix, AZ: Author.

83 Sickmund, M., Adams, B., Puzzanchera, C., Livsey, S., \& KNOll, C. (2008, November 14). LATINOS IN THE JUVENILE JUSTICE SYSTEM. THE OFFICE OF JuVENILE JUSTICE AND

Delinguency Prevention. Presentation to the American Society of Criminology, St. Louis, MO.

84 IBID.

85 IBID.

86 IBID

87 IBID.

88 IBID.

89 Author's calculations from Sickmund, M., Adams, B., Puzzanchera, C., Livsey, S., \& KnOll, C. (2008, November 14). Latinos in the JUVENile JUSTICE System. THe OfFice of Juvenile Justice and Delinquency Prevention. Presentation TO THE American SOCiety of CRiminology, St. Louis, MO.

90 Bell, J. \& Ridolfi, L.J. (2008, DeCember). Adoration of THE QUESTION: REFLECTIONS ON THE FAILURE TO REDUCE RACIAL $\mathcal{E}$ ETHNIC DISPARITIES IN THE JUVENILE JUSTICE SYSTEM. SAN Francisco, CA: The W. Haywood Burns Institute.

91 Pew Hispanic Center. (2006). Table 19: Language spoKEN AT HOME AND ENGLISH-SPEAKING ABILITY BY AGE, RACE AND ETHNICITy. Statistical PoRTRAit OF LATINOS IN THE UNITED States. WASHington, DC: Author.

92 Fry, R. \& GonZAles, F. (2008, August). ONE-IN-FIVE AND GROWING FAST: A PROFILE OF LATINO PUBLIC SCHOOL STUDENTS. Washington, DC: PeW Hispanic Center.

93 Hakimzadeh, S. \& Cohn, D. (2007, November). English usage AMONG Hispanics in the United States. Washington, DC: PeW Hispanic Center.

94 NATIONAL COUNCIL OF LA RAZA. (2008). OVERCOMING LANGUAGE AND CULTURE BARRIERS USING EVIDENCE BASED-PRACTICE. Prepared For MACARTHur Foundation, Models For Change. WASHINGTON, DC: AUTHOR. 
95 Vera InStitute of JUSTICE. (2007, OCtOBER). IF PARENTS DON'T SPEAK ENGLISH WELL, WILL THEIR KIDS GET LOCKED UP? NEW YORK, NY: AUTHOR.

96 HeRnandez, D.J. (2008). ChILdREN IN IMMIGRANT FAMILIES: KEY TO AMERICA'S FUTURE. IN BIG IDEAS FOR CHILDREN: InVEsting in OUR Nation's Future. Washington, DC: First FOCUS.

97 United States Department of Justice. (2003, April). LetTer From Assistant AtTorney General Ralph Boyd JR. TO

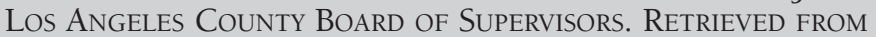
HTTP://WWW.USDOJ.GOV/CRT/SPLIT/DOCUMENTS/LA COUNTY JUVENILE FINDLET.PDF.

98 Sickmund, M, Sladky, T.J., AND Kang, W. (2008). Census of Juveniles in Residential Placement Databook. Available FROM HTTP://WWW.OJIDP.NCJRS.GOV/OJSTATBB/CJRP/.

99 Sickmund, M., Sladky, T.J., Kang, W., \& Puzzanchera, C. (2008). EAsy ACCESS to THE CENSUS Of JUVENILES IN

Residential Placement. Available from

HTTP://OJJDP.NCJRS.GOV/OJSTATBB/EZACJRP/.

100 IBID.

101 Sickmund, M., Adams, B., Puzzanchera, C., Livsey, S., \& KNOll, C. (2008, November 14). Latinos IN THE JUVENILE JUSTICE SYSTEM. THE OFFICE OF JuVENILE JUSTICE AND

Delinguency Prevention. Presentation to the American Society of Criminology, St. Louis, MO.

102 IBID.

103 IBID.

104 IBID.

105 IBID.

106 IBID.

107 Juvenile Detention Alternatives Initiative. (2006).

DETENTION FACILITY SELF-ASSESSMENT: A PRACTICE GUIDE TO JUVENILE DETENTION REFORM. BALTIMORE, MD: THE ANNIE E. CASEY FOUNDATION.

108 Sickmund, M., Sladky, T.J., Kang, W., \& Puzzanchera, C. (2008). EASY ACCESS TO THE CENSUS OF JUVENILES IN RESIDENTIAL PlaCEMENT. RETRIEVED FROM: HTTP://OJJDP.NCJRS.GOV/OJSTATBB/EZACJRP/. 
109 Sickmund, M., Adams, B., Puzzanchera, C., Livsey, S., \& KNOLl, C. (2008, November 14). LATINOS IN THE JUVENILE JUSTICE SYSTEM. The OfFICE OF JUVENILE JustiCE AND

Delinguency Prevention. Presentation to the American Society of Criminology, St. Louis, MO.

110 IBID.

111 IBID.

112 Sickmund, M., Sladky, T.J., Kang, W., \& Puzzanchera, C. (2008). EASy ACCESS to THE CENSUS OF JuVENILES IN RESIDENTIAL Placement. RETRIEVED FROM HTTP://OJJDP.NCJRS.GOV/OJSTATBB/EZACJRP/. 113 Sickmund, M., Sladky, T.J., AND Kang, W. (2008). Census of JuVEniles in Residential PlaCEMENT DATABOOK. AVAILABLE FROM HTTP://WWW.OJJDP.NCJRS.GOV/OJSTATBB/CJRP/.

114 Griffin, Patrick. 2008. "National Overviews." State juvenile justice Profiles. Pittsburgh, PA: National Center FOR JUVENILE JUSTICE. RETRIEVED FROM HTTP://WWW.NCII.ORG/STATEPROFILES/.

115 IBID.

116 IBID. CONNECTICUT CURRENTLY TRIES ALL 16- AND 17YEAR-OLDS AS ADULTS BUT PUBLIC ACT 07-4 PASSED IN 2007 AND WILL RAISE THE MAXIMUM AGE OF JUVENILE JURISDICTION FROM 15 TO 17 STARTING IN 2010. ILLINOIS CURRENTLY TRIES ALL 17 YEAR-OLDS AS ADULTS, PUBLIC ACT 95-1031 SIGNED INTO LAW IN 2009 WILL ALLOW 17-YEAR-OLD MISDEMEANANTS TO BE TRIED IN THE JUVENILE COURTS AND WILL SET UP A TASK FORCE TO LOOK AT THE ISSUES SURROUNDING RAISING THE AGE FOR FELONIES AS WELL.

117 IBID.

118 IBID.

119 Campaign for Youth Justice. (2007). THE CONSEQUENCES AREN'T MINOR: THE IMPACT OF TRYING YOUTH AS ADULTS AND STRATEGIES FOR REFORM. WASHINGTON, DC: AUTHOR.

120 Sickmund, M., Adams, B., Puzzanchera, C., Livsey, S., \& KNOLl, C. (2008, November 14). LATINOS IN THE JUVENILE JUSTICE SYSTEM. THE OfFICE OF JUVENILE JUSTICE AND

Delinguency Prevention. Presentation to the American Society of Criminology, St. Louis, MO.

121 Author's calculations from Puzzanchera, C., Sladky, A. AND KANG, W. (2008). EASY ACCESS to JUVENILE POPULATIONS: 1990-2007. PitTsburgh, PA: NATIONAL CENTER FOR JuVEnile Justice. AVAilable from 
HTTP://WWW.OJJDP.NCJRS.GOV/OJSTATBB/EZAPOP; GRIFFIN, P. (2008). National OVERVieWs. State JuVEnile Justice Profiles. Pittsburgh, PA: National Center for Juvenile Justice. AVAILABLE: HTTP://WWW.NCII.ORG/STATEPROFILES; AND Arya, N. (2007, November). JAILING JUVENILES: THE DANGER OF INCARCERATING YOUTH IN ADULT JAILS IN AMERICA. Washington, DC: The Campaign For Youth Justice.

122 IBID.

123 IBID.

124 IBID.

125 Puzzanchera, C., Sladky, A. And Kang, W. (2008). Easy ACCESS to JUVENILE POPUlations: 1990-2007. PitTsburgh, PA: National Center for Juvenile Justice. Available from HTTP://WWW.OJIDP.NCJRS.GOV/OISTATBB/EZAPOP; GRIFFIN, P. (2008). National overvieWs. State JuVEnile Justice Profiles. Pittsburgh, PA: National Center for Juvenile JUSTICE. AVAILABLE: HTTP://WWW.NCJJ.ORG/STATEPROFILES; AND Arya, N. (2007, November). JAILING JUVENILES: THE DANGER OF INCARCERATING YOUTH IN ADULT JAILS IN AMERICA. Washington, DC: The Campaign For Youth Justice.

126 Campaign for Youth Justice. (2007). THE CONSEQUENCES AREN'T MINOR: THE IMPACT OF TRYING YOUTH AS ADULTS AND STRATEGIES FOR REFORM. WASHINGTON, DC: AUTHOR.

127 California Department of Justice. (2007, August). JuVenile JUStice in CALIFORNia 2007. SaCramento, CA: Criminal Justice Statistics Center.

128 IBID.

129 IBID.

130 IBID.

131 IBID.

132 IBID.

133 Children's Action Alliance. (2003, June). Prosecuting JUVENILES IN THE ADULT CRIMINAL JUSTICE SYSTEM: KEY ISSUES And recommendations for Arizona. Phoenix, AZ: Author. 134 Puzzanchera, C., Sladky, A. And Kang, W. (2008). Easy ACCESS TO JUVENILE POPULATIONS: 1990-2007. AVAILABLE FROM HTTP://WWW.OJJDP.NCJRS.GOV/OJSTATBB/EZAPOP/. 
135 Administrative OfFice of the Courts Juvenile Justice SERVICES DiVISION. (2008). JUVENILES PROCESSED IN THE ARIZONA COURT SYSTEM FY 2007. PhOENIX, AZ: ARIZONA SUPREME COURT.

\section{IBID.}

137 West, H.C. \& Sabol, W.J. (2009, March). Prison INMATES AT MIDYEAR 2008 - STATISTICAL TABLES. WASHINGTON, DC: U.S. Department of Justice, Bureau of Justice STATISTICS.

138 JusZKiEWICZ, J. (2007, OCTOBER). TO PUNISH A FEW: TOO MANY YOUTH CAUGHT IN THE NET OF ADULT PROSECUTION. Washington, D.C.: Campaign For Youth Justice.

139 Beck, A.J., Harrison, P.M., Adams, D.B. (2007, August). SEXUAL VIOLENCE REPORTED BY CORRECTIONAL AUTHORITIES, 2006. Washington, D.C.: U.S. DePartment of JustiCE, Office of Justice Programs, Bureau of Justice Statistics; and Beck, A.J., Harrison, P.M. (2006, July). SEXual ViolenCE REPORTED BY CORRECTIONAL AUTHORITIES, 2005. WASHINGTON, D.C.: U.S. Department of Justice, OfFice of Justice Programs, Bureau of Justice Statistics.

140 SNyder, H.N., SiCKMUND, M. (2006). JUVENILE OFFENDERS AND VICTIMS: 2006 NATIONAL REPORT. WASHINGTON, DC: U.S. Department of Justice, OfFice of Justice Programs, OfFice of Juvenile Justice And Delinquency PREVEntion.

141 Krisberg, B. (2006, June) TESTIMONy BY BARRY KRISBERG. Boston, MA: National Prison Rape Elimination COMMISSION.

142 Arya, N. (2007, November). JAILING JUVEniles: The DANGER OF INCARCERATING YOUTH IN ADULT JAILS IN AMERICA. Washington, DC: The CAMPaign FOR Youth Justice.

143 Mumola, C.J. (2005, August). Suicide AND HOMiCidE IN STATE PRISONS AND LOCAL JAILS. WASHINGTON, D.C.: U.S. Department of Justice, OfFice of Justice Programs, Bureau OF JUSTICE StaTistics.

144 Office of Statistics and Programming, National Center for Injury Prevention and Control, CDC WebBASED INJURY StATISTICS QUERY AND REPORTING SYSTEM (2007, JULY). 2000 - 2002, UNITED STATES SUICIDE INJURY DEATHS AND RATES PER 100,000 ALL RACES, BOTH SEXES, AGES 14 TO 17. Atlanta, GA: Centers for Disease Control And PREVENTION. 
145 Centers for Disease Control and Prevention. (2008, JUNE). YOUTH RISK BEHAVIOR SURVEILLANCE - UNITED STATES, 2007. MMWR 2008;57(No.SS-4). AtLANTA, GA: Author.

146 Woolard, J.L., Odgers, C., Lanza-Kaduce, L., Daglis, H. (2005). JUVENILES WITHIN ADULT CORRECTIONAL SETTINGS: LEGAL PATHWAYS AND DEVELOPMENTAL CONSIDERATIONS.

IntERNATIONAL JOURNAL OF Forensic MENTAL HEALTH, 4(2), 1-18. AVAILABLE From HTTP://WWW.IAFMHS.ORG/FILES/WOOLARDSPR05.PDF.

147 OF THOSE 10 STATES, ONLY TWO MANDATE IT FOR PARTICULAR GROUPS OF TRANSFERRED CHILDREN. FOR MORE INFORMATION SEE, ARYa, N. (2007, NOVEMBER). JAILING JUVENILES: THE DANGERS OF INCARCERATING YOUTH IN ADULT JAILS IN AMERICA. Washington, DC: The Campaign for Youth Justice.

148 IBID.

149 Author's calculations from Puzzanchera, C., Sladky, A. AND KANG, W. (2008). EASY ACCESS TO JUVENILE POPULAtions: 1990-2007. PitTsbuRgh, PA: National Center FOR Juvenile Justice. Online. Available:

HTTP://WWW.OJJDP.NCJRS.GOV/OJSTATBB/EZAPOP; AND ARYA, N. (2007, NOVEMBER). JAILING JUVENILES: THE DANGER OF INCARCERATING YOUTH IN ADULT JAILS IN AMERICA. WASHINGTON, DC: The CAmpaign For Youth Justice.

150 IBID.

151 JUSZKIEWICZ, J. (2007, OCTOBER). TO PUNISH A FEW: TOO MANY YOUTH CAUGHT IN THE NET OF ADULT PROSECUTION. Washington, D.C.: Campaign For Youth Justice.

152 Hartney, C. \& Vuong, L. (2009, March). Created EQUAL: RACIAL AND ETHNIC DISPARITIES IN THE U.S. CRIMINAL JUSTICE SySTEM. San Francisco, CA: National COUNCIL ON CRIME AND DELINQUENCY.

153 IBID.

154 National Council of La Raza. (2008). Overcoming LANGUAGE AND CULTURE BARRIERS USING EVIDENCE BASED-PRACtice. Prepared for Macarthur Foundation, Models for Change. Washington, DC: Author.

155 IBID.

156 IBID.

157 IBID. 
158 IBID.

159 Gies, G., Cohen, F., \& Villaruel, F. (2006, August). INTERVENTION. IN DisPROPORTIONATE MINORITY CONTACT Technical Assistance Manual. Washington, DC: Office of Juvenile Justice And Delinquency Prevention.

160 See Hynton Hoytt, E., Schiraldi, V., Smith, B.V., \& ZiEDENBERG, J. (2001). REDUCING RACIAL DISPARITIES IN JUVENILE DETENTION. PATHWAYS TO JUVENILE DETENTION REFORM, Volume 8. The Annie E. Casey Foundation.

161 See The W. Haywood Burns Institute Website, WWW.BURNSINSTITUTE.ORG

162 See The Models for Change Website, HTTP://WWW.MODELSFORCHANGE.NET/

163 See The Center for Children's Law and Policy WebSITE, HTTP://WWW.CCLP.ORG/ 164 OFFICE OF JUVENILE JUSTICE AND DELINQUENCY PREVENTION. (2004, SEPTEMBER). DisPROPORTIONATE MINORITY CONFINEMENT 2002 UPDATE. WASHINGTON, DC: AUTHOR.

165 National Council of La Raza. (2008). OVERComing LANGUAGE AND CULTURE BARRIERS USING EVIDENCE BASED-PRACtice. Prepared for MacArthur Foundation, Models for Change. Washington, DC: Author.

166 Juvenile Detention Alternatives Initiative. (2008). JDAI HELPDESK. BALTIMORE, MD: ANNIE E. CASEY Foundation. AVAILABLE

HTTP://WWW.JDAIHELPDESK.ORG/PAGES/SANTACRUZCOUNTYCA.AS $\underline{\text { PX. }}$

167 Gies, G., Cohen, F., \& Villaruel, F. (2006, August). InTERVENTION. IN Disproportionate MinORITY CONTACT Technical Assistance Manual. Washington, DC: Office of JuVEnile Justice ANd DELINQUenCy PREVEntion.

168 Juvenile Detention Alternatives Initiative. (2008). JDAI HELPDESK. BALTIMORE, MD: ANNiE E. Casey Foundation. AVAILABLE

HTTP://WWW.JDAIHELPDESK.ORG/PAGES/SANTACRUZCOUNTYCA.AS $\underline{\text { PX. }}$

169 Gies, G., Cohen, F., \& Villaruel, F. (2006, August). INTERVENTION. IN DisPROPORTIONATE MINORITY CONTACT TeChnical Assistance Manual. Washington, DC: Office of JuVEnile Justice AND Delinquency PREVEntion. 
170 The Annie E. Casey Foundation. (2008). A roadmap FOR JUVENILE JUSTICE REFORM. 2008 KIDS COUNT ESSAY AND DATA BOOK. BALTIMORE, MD.

170 Gies, G., Cohen, F., \& Villaruel, F. (2006, August). INTERVENTION. IN DisPROPORTIONATE MINORITY CONTACT Technical Assistance Manual. Washington, DC: Office of JuVEnile Justice And Delinguency PREVEntion.

171 Juvenile Detention Alternatives Initiative. (2008). JDAI HELPDESK. BAltimore, MD: ANNIE E. CASEy Foundation. AVAILABLE HTTP://WWW.JDAIHELPDESK.ORG/PAGES/SANTACRUZCOUNTYCA.AS $\underline{\text { PX. }}$

172 Griffin, P. (2008). Doing Something About DMC. Pennsylvania Progress. Pittsburgh, PA: National Center FOR JUVENILE JUSTICE.

173 D. SCHOENBERG, PERSONAL E-MAIL COMMUNICATION WITH AUTHOR, MAY 6, 2009.

174 Washington OfFice on Latin America. (2008, OCTOBER). DARING TO CARE: COMMUNITY-BASED RESPONSES TO YOUTH GANG VIOLENCE IN CENTRAL AMERICA AND CENTRAL AMERICAN IMMIGRANT COMMUNITIES IN THE UNITED STATES. WASHINGTON, DC.

175 VAn Gelder, S.R. (SPRing, 2003). Our Planet, OUR SELVES, URBAN PEACEMAKER: AN INTERVIEW WITH DANIEL "NAne" Alejandrez. YES! Magazine

176 SeE Barrios Unidos Website, HTTP://WWW.BARRIOSUNIDOS.NET

177 Southwest Key Program. (N.D.). 2007 AnNUAl REPORT. Austin, TX: Author.

178 M. RinCON-GALlARDO, PERSONAL E-MAIL COMMUNICATION WITH AUTHOR, MAY 6, 2009.

179 SEE Homeboy INDUSTRIES WEBSite HTTP://WWW.HOMEBOY-INDUSTRIES.ORG

180 Salazar \& Wilberg. (2006, Spring). Peace Signs, JobS not jail. Agenda Magazine. Washington, DC: National COUNCIL OF LA RaZA.

181 SeE Homeboy Industries Website HTTP://WWW.HOMEBOY-INDUSTRIES.ORG 
Notes 
Notes

90 


\section{ACKNOWLEDGEMENTS}

Neelum Arya - Research and Policy Director, Campaign for Youth Justice Ian Augarten - Program Associate, Campaign for Youth Justice Janet Murguía - President and CEO, National Council of La Raza Juan Sánchez - Founder and CEO, Southwest Key Programs, Inc. Cassandra Villanueva - Legislative Analyst, National Council of La Raza Francisco Villarruel - Outreach and Engagement Senior Fellow and Professor of Family and Child Ecology, Michigan State University

The authors would like to specifically recognize the Congressional Hispanic Caucus, the Congressional Hispanic Caucus Institute, the League of United Latin American Citizens (LULAC), the Mexican American Legal Defense \& Education Fund (MALDEF), the Julian Samora Research Institute, the Youth Law Center, Mark Soler, and the many other dedicated people and partners who worked on the Building Blocks for Youth Initiative, a multi-year initiative from 1999 to 2005, whose groundbreaking research in ¿Dónde Está la Justicia? paved the way for this policy brief.

In addition, the authors would like to acknowledge the following individuals for their assistance in preparing this brief: advisors to the brief (Angela Arboleda, Eduardo Ferrer, Rosa M. Grillo, Raquel Mariscal, Orlando Martinez, Marcia Rincón-Gallardo, Dana Shoenberg, Javier Stauring); Melissa Sickmund and Patrick Griffin at the National Center for Juvenile Justice; Barry Krisberg and the National Council on Crime and Delinquency; the National Council of La Raza staff and Affiliate Network; the Campaign for Youth Justice staff, fellows, and consultants (Bieta Andemariam, Sarah Baker, Grace Bauer, Jennifer Comer, Erin Davies, Kate Figiel, Roger Ghatt, Christina Gilbert, Shanta' Gray, Laura Jones, Amanda Ponce, Liz Ryan, Jessica Sandoval, Eric Solomon, Tarun Wadhwa); and Audrey White and colleagues at Marketing Resource Solutions. 


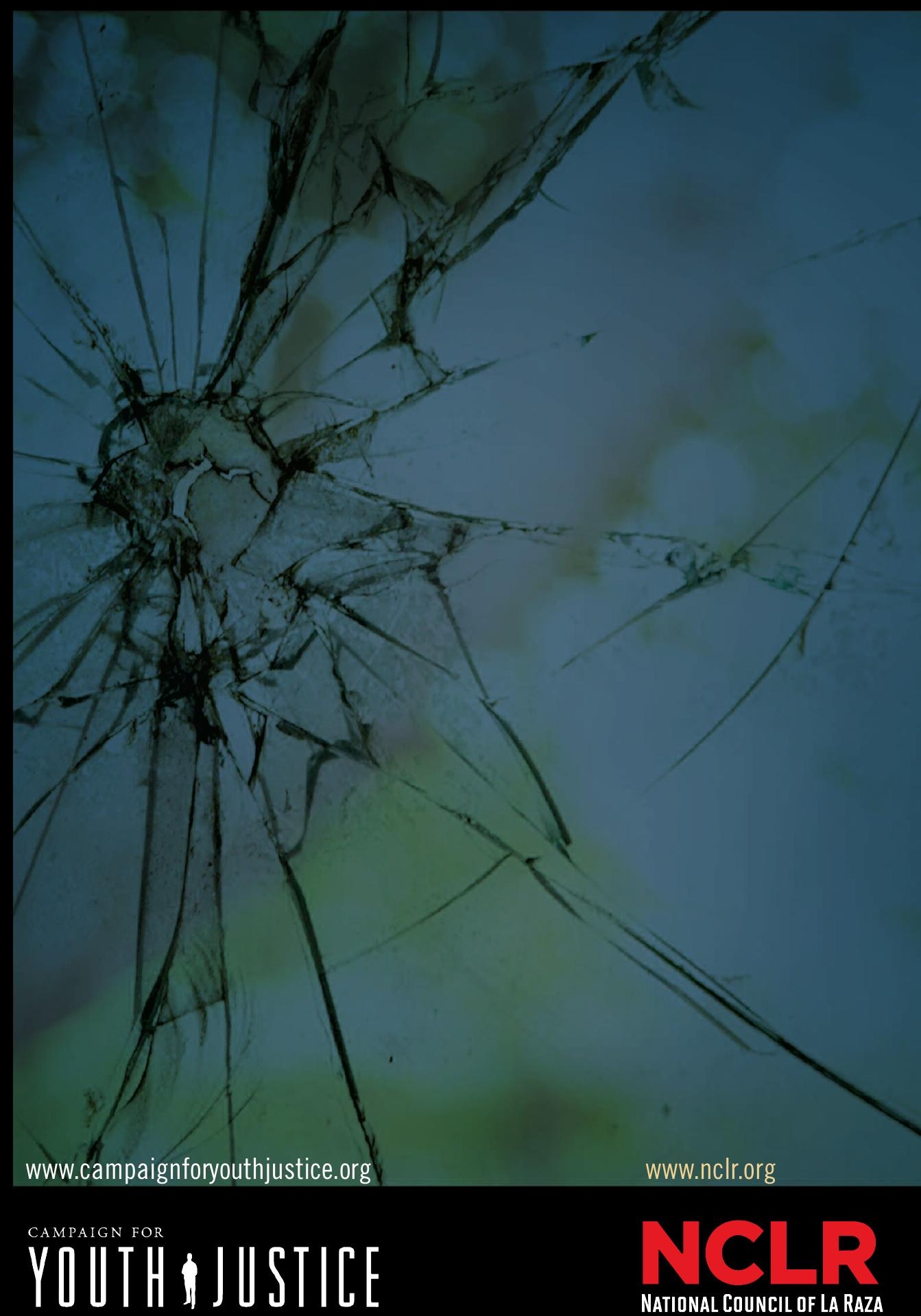

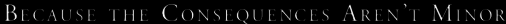

